\title{
ÉRZELMI ÉS TÁRSAS MINTÁZATOK A FAPOFA- (STILL FACE) HELYZETBEN 3-6 HÓNAPOS CSECSEMŌKNÉL
}

\author{
HÁMORI ESZTER ${ }^{1}$ - SIMON RÉKA BARBARA ${ }^{1}-$ \\ MÁRKUS LILLA VIKTÓRIA ${ }^{1,2}$ - FARKAS FLÓRA ${ }^{1}$
}

\author{
${ }^{1}$ PPKE BTK Pszichológiai Intézet, Fejlôdés- és Klinikai Gyermeklélektan Tanszék \\ ${ }^{2}$ Lóczy Alapítvány a Gyermekekért \\ E-mail: hamori.eszter@btk.ppke.hu
}

Benyújtva: 2020. január 3. - Elfogadva: 2020. október 9.

Háttér és célkitǔzések: A fapofa-paradigma (Tronick, Als, Adamson, Wise és Brazelton 1978) szokatlan megszakitásos helyzetet teremt az anya-csecsemó interakcióban, igy az egyik leggyakrabban alkalmazott eljárás az egyéni és a diádikus társas és stressz-szabályozási minták vizsgálatában csecsemókorban. A kódrendszerek sokfélesége miatt azonban ellentmondásosak az eredmények a mintázatok azonositásában. Jelen tanulmányban egyik célunk egy olyan globális kódrendszer kialakitása volt, amellyel külön vizsgálhatjuk a társas viselkedés és az érzelemkifejezés szerepét a regulációs mintázatok formálódásában. Másik célunk a fapofa- és a regulációs szakaszokra jellemző társasviselkedés-mintázatok keresése és a két szakasz közötti változásuk vizsgálata volt.

Módszer: 101 3-6 hónapos, tipikusan fejlôdô csecsemô-anya párral vettük fel a fapofa-paradigmát. A csecsemók érzelmi állapotát, társas viselkedését és stressz-szintjének alakulását a jelen kutatásra kidolgozott Érzelmi és Társas Szabályozási Mintázatok Globális Kódrendszerével értékeltük a fapofa-és a regulációs szakaszokban.

Eredmények: Az érzelmi dimenzió mintázatai egyértelmúen mutatták a klasszikus fapofa-hatást a mintában. A társas dimenzióban négy fö mintázatot definiáltunk: anyára pozitív, anyára negatív, anyára vegyes és minimalizáló. A fapofa-szakasz domináns társas mintázatai eltéróen jósolták be a regulációs szakasz társas mintázatait. A társas viselkedés két szakasz közötti változásában a stressz-szinttel való összefüggésük mentén adaptív, rizikós és többesélyes mintázatokat azonositottunk. Klaszterelemzéssel egy Nyugodt és egy Nyúgös csoport különült el, amiben az érzelmi dimenzió differenciáló szerepe emelkedett ki a társas dimenzióval szemben.

Következtetések: Eredményeink alátámasztják, hogy már 3 hónapos kortól jelen lehetnek a stressz szabályozására specifikus, egyéni regulációs mintázatok. Kódrendszerünk a globális dimenziók alkalmazásának fontosságára hívja fel a figyelmet, amely informálhat az összetett érzelmi, valamint a társasviselkedés-mintázatok és a stresszreguláció kölcsönkapcsolatáról, és így hozzájárulhat azok adaptív vagy maladaptív jellegének felméréséhez.

Kulcsszavak: fapofa- (Still Face) paradigma, 3-6 hónapos csecsemók, Érzelmi és Társas Szabályozási Mintázatok Globális Kódrendszere, adaptív és rizikós regulációs mintázatok 


\section{BEVEZETÉS}

A korai érzelmi szabályozás sajátosságainak és kialakulásának kutatásai a kötôdéselmélet (Bowlby, 1969; Ainsworth, 1985) megszületése óta a gondozói kapcsolat finom mintázatainak megismerésére helyezték a hangsúlyt. Az egyik elsô olyan kísérleti helyzet, amely a csecsemókori regulációs minták szervezôdésére szolgáltatott empirikus adatokat, a laboratóriumi helyzetben végzett fapofa-paradigma (Tronick és mtsai, 1978) volt. Tronick és munkatársai eredetileg az anyai depresszió szimulálására találták ki a kísérleti helyzetet. Arra voltak kíváncsiak, hogyan reagálnak 1-4 hónapos csecsemók arra, ha a szemtôl szemben interakció során azt tapasztalják, hogy az anya arca kifejezéstelenné válik, és hirtelen, minden átmenet nélkül megszünteti gyermekével az érzelemteli kommunikációt. A rövid, 6 perces videófelvétel elsô, kötetlen interakciós szakaszában arra kérték az anyát, hogy beszélgessen csecsemôjével úgy, ahogy otthon szokott. A második, ún. fapofa-szakaszban szakítsa meg az interakciót, és vegyen fel egy semleges, mozdulatlan arcot, de folyamatosan nézzen gyermekére, jelezvén, hogy figyel, csak a kommunikációt szüntette be. A harmadik, ún. újratalálkozási vagy regulációs szakaszban állítsa helyre az interakciót, beszélgessen újra csecsemôjével, és nyugtassa meg, ha elkeseredett volna.

A fapofa-helyzet azáltal, hogy szokatlan megszakításos helyzetet teremt a kommunikációban, és az anya érzelmi hozzáférhetetlenségét, válaszkészségének megszakadását modellálja, a szeparációs stresszhez hasonló feszültséget kelt a csecsemôkben (Cohn, Campbell és Ross, 1992; Cohn és Tronick, 1987; Tronick, 2007; Tronick és mtsai, 1978). A helyzet stresszkeltô voltát számos, a stressz fiziológiai jeleit, például a HPA-tengely aktivitását vizsgáló kutatás támasztotta alá (az összefoglalót lásd Provenzi, Giusti és Montirosso, 2016). A paradigmát máig számos kutatás alkalmazza a korai érzelmi és társas fejlôdés sajátosságainak felmérésére 2 és 9 hónapos kor között. Az eljárással vizsgálni lehet a szemtôl szembeni interakciók jellemzóit a kötetlen, ,játékos” szakaszban, a csecsemó stresszre adott viselkedéses válaszait a fapofa-szakaszban, valamint az anya-csecsemó pár stresszhelyzetet követô szabályozási stratégiáit a regulációs szakaszban (az összefoglalót lásd Barbosa, Beeghly, Gonçalves és mtsai, 2019; Barbosa, Beeghly, Moreira és mtsai, 2018; Mesman, Van IJzendoorn és Bakermans-Kranenburg, 2009; Tronick, 2007).

\section{A fapofa-hatás}

Az eredeti paradigmát többfajta verzióban alkalmazták a késôbbiekben: eltérô idôi paraméterekkel és változatos elrendezésekben. A 2000-es évek közepéig végzett kutatások metaelemzése (Mesman és mtsai, 2009) megerôsítette, hogy az eljárás különféle változataitól, valamint az életkortól és a rizikótényezóktôl függetlenül a csecsemôk túlnyomó többségénél megjelenik az ún. fapofa-hatás. Nevezetesen, a fapofa-szakaszban a csecsemók kevesebbet néznek anyjukra, csökken a pozitív érzelmek kifejezése, és enyhén feszültté válnak a kötetlen, játékos szakaszhoz képest. Egy részük kerüli az anya arcára pillantást, és a környezet tárgyai vagy önmaga felé fordítja a figyelmét. Vannak csecsemók, akik anyára nézéssel és mosolygással próbálják ót „megszólítani”. Ezek a viselkedések több kutatócsoport szerint is szervezett, egyéni viselkedéses stratégiákat 
mutatnak, amelyek segítségével a csecsemô képes a kommunikáció szokatlan megszakítása keltette feszültség szabályozására, ha az rövid ideig tart (Murray és Trevarthen, 1985; Tronick és mtsai, 1978; Weinberg és Tronick, 1996).

\section{A fapofa-helyzet regulációs szakasza}

A fapofa-helyzet regulációs szakasza lehetôséget nyújt annak vizsgálatára, hogyan állítja helyre a harmonikus interakciót az anya-csecsemó pár akkor, ha maga a feszültségkeltố helyzet, azaz a fapofa-szakasz megszúnt. A csecsemôk általában aktívan reagálnak az anya kommunikációt helyreállító törekvésére, és részt vesznek a kölcsönös összehangolódás helyreállításában, miközben stressz-szintjük csökken. A regulációs szakasz lefolyásában is jelentôs egyéni különbségeket figyeltek meg. A csecsemók egy kisebb része megnyugtathatatlan lesz, esetenként kiborul, miközben vagy fenntartja, vagy éppenséggel megszakítja az anyával a kommunikációt. A kutatások többsége leírta az ún. átcsapási hatást (összefoglalást lásd Mesman és mtsai, 2009), amikor a fapofa-szakaszban viszonylag nyugodt csecsemôk egy része a regulációs szakasz elején kezd nyúgösködni és tiltakozni, amikor az anya már ismét kezdeményezô és válaszkész. A harmonikus, összehangolt, kölcsönösen örömteli interakciók helyreállításának képessége a regulációs szakaszban biztos jelzője az anya-csecsemô pár hatékony affektív szabályozási képességének (Coppola, Aureli, Grazia és Ponzetti, 2015; Tronick és mtsai, 1978; Weinberg és Tronick, 1996).

\section{Mintázatok a fapofa-helyzetre adott reakciókban}

A fapofa-paradigmával végzett kutatások egyik fố kérdése volt, hogy léteznek-e normatív mintázatok a szokatlan kommunikációs helyzet keltette stressz szabályozásának fejlôdésében, és ha igen, azok milyen viselkedéses dimenziók mentén írhatók le.

A mintázatok felrajzolásához használt elsô kódrendszerek (Tronick és mtsai, 1978; Tronick, Als és Brazelton, 1980) elsô lépésben az elemi viselkedések megjelenését és idôtartamát rögzítették idôsorosan, másodperces bontásban. A csecsemô, illetve az anya nézésiránya és affektív jelzései, ezek minôsége, továbbá a testtartás, a vokalizáció, valamint a csecsemô tárgyorientációja segítségével hoztak létre viselkedéses kombinációkat. Ez alapján négy fó jellemzô mintázatot definiáltak: a társas bevonódást, a tárgyra irányulást, a passzív visszahúzódást és az aktív tiltakozást. Tronick a kódrendszerhez kapcsolódó Kölcsönös Regulációs Modelljében (Mutual Regulation Model, Tronick, 2007) feltételezte, hogy a fapofa-helyzet a csecsemô arra vonatkozó veleszületett elvárását hágja át, hogy a társas interakciókban a reciprocitás elve dominál. A jellemzó mintázatokat olyan szabályozási stratégiaként értelmezte, amely jelzi, hogy a csecsemô észleli a reciprocitás megszakadását, és mivel az feszültséget kelt, ezért törekszik helyreállítani azt. Minél hatékonyabb egy mintázat, annál jobban támogatja az egyéni érzelemszabályozási készségek fejlôdését, és fordítva is, minél kevésbé hatékony egy interaktív stratégia, annál kevésbé adaptív az érzelem szabályozása.

Tronick és munkatársai kódrendszereit késóbb több munkacsoport is továbbfejlesztette (Montirosso, Casini, Provenzi, Putnam, Morandi és mtsai, 2015; Provenzi, Olson, 
Montirosso és Tronick, 2016; Reck, Noe, Cenciotti, Tronick és Weinberg, 2009). Amellett, hogy e kódrendszerek között sok hasonlóságot ismerhetünk fel, kidolgozásukban megfigyelhetô egy konceptuális fejlődés is a kódolási dimenziók választásában. Így például Reck és munkatársai (2009) kódrendszere a korábbiakhoz képest jóval részletesebb és tartalmasabb információt nyújtott a társas összekapcsolódás és szétkapcsolás folyamatairól, és ebben a csecsemó és a gondozó kölcsönös szabályzó viselkedésének tipikus mintázatairól. A kódrendszer hátterében is komplexebb, a Tronick- (2005) féle Dyadic States of Consciousness (A tudat diádikus állapotai) modellje állt, amely feltételezte, hogy a kölcsönös szabályozás alakításában a csecsemó aktívan vesz részt. Társas viselkedésének mintázata kulcsfontosságú, mivel kifejezi, hogy érti és értelmezi a kommunikációs helyzet kölcsönösségét és koherenciáját, és ennek megszakadásakor törekszik arra, hogy helyreállítsa a gondozó jelentésadó és koherenciateremtô szerepét. A társas viselkedés csecsemôre jellemzó egyéni mintázatai tehát nem csupán a stresszkeltô helyzetre adott reakciót, hanem a csecsemó-anya pár jellemzô kapcsolódási folyamatainak reprezentációit, és ezen belül a csecsemó jellemzó szabályozó stratégiáit tükrözik.

\section{Életkori és nemi különbségek}

A jellemzô mintázatok leírásával párhuzamosan kérdésként merült fel a nem, az életkor és a gondozói sajátosságok lehetséges szerepe a mintázatok szervezódésében. Kérdés volt az is, hogy vajon egyedi, csak az adott gondozói kapcsolatra jellemzô mintázatokról van szó, vagy olyan társas viselkedési stratégiákról, amelyeket a csecsemó minden más kapcsolatban hasonlóan alkalmaz.

Mesman és munkatársai (2009) 31 kutatást összegzô áttekintô tanulmánya ellentmondásos eredményekre világított rá. A kutatások többsége a várttal szemben nem talált különbséget fiúk és lányok között a fapofa-reakcióban, míg más kutatások a fiú-anya párok hatékonyabb összehangolódására és kölcsönös regulációjára hoztak bizonyítékot. A fiúk nagyobb sérülékenysége emelkedett ki depressziós, illetve szorongásos zavarban szenvedô anyáknál. A nemi különbségek fejlôdési rizikóval született csecsemôknél, illetve az anya érzelmi vagy mentális zavara esetén domborodtak ki. A normatív mintákon kapott ellentmondásos eredmények azonban máig nyitva hagyták a nemi különbségekre vonatkozó kérdést (Carter, Mayes és Pajer, 1990; Provenzi és mtsai, 2016; Tronick, 2007).

Az életkor szerepét illetôen Mesman és munkatársai (2009) metaelemzése megerôsítette a feltevést, hogy a csecsemôk társas viselkedése és érzelemszabályozási stratégiái a fapofa-helyzetben az életkor elôrehaladtával egyre összetettebbé válnak: nemcsak a viselkedésrepertoárjuk bôvül, hanem az affektív állapotaikat is egyre komplexebb formákban képesek kifejezni és felhasználni azt a társas kommunikáció céljainak elérésében. Bizonyos viselkedésformák elhalványulnak az idôvel (pl. csökken a tekintet irányának elterelôdése az anyáról, vagy a semleges érzelemkifejezés), míg mások felerôsödnek, és beépülnek egy összetettebb konfigurációba (pl. az anyára pillantás homlokráncolással és csodálkozó kifejezéssel, valamint az anyára pillantás kommunikációs kezdeményezéssel). A mintázatok kapcsolatspecifikusságát jelzi, hogy körülbelül 4-5 hónapos kortól a csecsemôk az anyával kialakított jellemzố mintázatukat nem 
viszik át számukra ismeretlen felnôttekre (Melinder, Forbes, Tronick, Fikke és Gredeback, 2010).

Összességében a kutatások többsége a szabályozási mintázatok fejlődésének életkori stabilitását látszott bizonyítani (Barbosa, Beeghly, Moreira és mtsai, 2018; Provenzi, Olson és mtsai, 2016). Mások szerint (lásd például Murray és Trevarthen, 1985; Stern, 1985 ) viszont a figyelem, a tárgymanipuláció fejlôdése, valamint a másodlagos interszubjektivitás kezdetén belépố új készségek módosíthatják az életkori jellemzóket. Az elsố kutatások elsôsorban a 6 és a 9 hónapos kort vélték jelentôs mérföldkônek (Cohn és Tronick, 1987; Tronick és Cohn, 1989). Késóbb több kutatás igazolta, hogy a 3, a 4, illetve az 5 hónapos kor is kiemelt fordulópont lehet a mintázatok életkori változásaiban (Beebe és mtsai, 2010; Bigelow, Power, Bulmer és Gerrior, 2018).

\section{Módszertani problémák: idôsoros mikroelemzés vagy globális viselkedéskategóriák?}

Az életkori és a nemi különbségekre, valamint a mintázatok stabilitására kapott ellentmondásos eredményeknek több munkacsoport szerint is módszertani és konceptuális okai lehettek. Barbosa és munkatársai (2018) szerint a fapofa-helyzet idósoros mikroelemzésein alapuló eredmények két fontos problémát vetettek fel. Az egyik magában az idôsoros elemzésben rejlik, amelynek során az elemi viselkedések (nézésirány, affektus, testmozgások stb.) megjelenési sorrendjét vagy azok gyakoriságát, illetve idôi arányát kalkulálták a fapofa-helyzet egyes szakaszaiban, és ez alapján képeztek jellemzô mintázati klasztereket. A másik probléma több szerzô szerint is (lásd például Barbosa és mtsai, 2018, 2019; Mesman és mtsai, 2009), hogy a klaszterek meghatározásában többnyire csak egyetlen dimenziót, például a nézésirányt vagy az affektív állapot minôségének elsôdlegességét vették figyelembe az idôsoros elemzéssel dolgozó kutatások. A regulációs mintázatok azonosításával kapcsolatos ellentmondások sorát azzal egészítenénk ki, hogy a társas viselkedés mintázatainak definiálása is eltért az egyes kutatásokban attól függôen, hogy annak mely dimenzióját részesítették a kutatók elônyben: az affektív színezetet és az egymásra orientálódást (Weinberg és Tronick, 1996), a kölcsönös reguláció célját, azaz a szétkapcsolást vs. összehangolást (Montirosso és mtsai, 2015) vagy a partnerek bevonódási szintjét (Reck és mtsai, 2009).

Bár a globális mintázatok keresése már az 1990-es évektôl megjelent a fapofa-paradigmát alkalmazó kutatásokban (lásd pl. Kogan és Carter, 1996), Reck és munkatársai (2009), valamint Barbosa és munkacsoportjai (2018) a korábbiakhoz képest új módszertani szemléletet vezettek be, amikor kódrendszereikben olyan globális viselkedéskategóriákat hoztak létre, amelyekben kombinálták az affektív és a társas szabályozás domináns jellemzôit. Mesman és munkatársai (2009) átfogó tanulmánya már korábban is felhívta a figyelmet a globális kódrendszerek szükségességére az idóigényes mikroelemzésekkel szemben. A globális kódrendszerek elônyeként emelték ki a szerzôk azt a törekvést, hogy ezek a kódrendszerek a kommunikáció és a stressz szabályozása szempontjából jelentésteli mintázatokat definiálnak, amelyek lehetôvé teszik a szelf-és a diádikus reguláció fejlôdése során létrejövô - például a kötôdési típusokra jellemzô - szabályozási mintázatokkal történô összehasonlítást és a mintázatok fejlôdését befolyásoló tényezôkre vonatkozó predikciók megfogalmazását. Ilyen kódrendszert 
dolgozott ki például Kogan és Carter (1996) a 6 hónapos kori fapofa-szakaszban és a 15 hónapos kötôdési viselkedésben megfigyelhetố csecsemố regulációs mintázatok összehasonlítására. Mesman és munkatársai (2009) szerint azonban e kódrendszerek kialakítása még a 2000-es évek végén is gyerekcipóben járt. Barbosa és munkacsoportja (2018; 2019), valamint Reck és munkatársai $(2009$; 2018) jelentôs elôrelépést tettek a globális kódrendszerek kialakítása terén, ám ezek hátterében még mindig hiányzik egy egységes modell, illetve koncepció, amely az egyes mintázatok jellemzóit és dimenzióit azonos keretben értelmezné. E kódrendszerek előnye, hogy jelentésteli mintázatokat definiálnak. A mintázatok definíciói azonban egy-egy kutatáson belül sem egységesek, amennyiben hol az érzelmi, hol a társas, hol pedig az önszabályozási viselkedést emelik ki az egyes mintázatok domináns jellemzőjeként. Azaz egy csecsemó vagy a distressz mértéke, vagy társas orientáltsága, vagy az önmegnyugtatási képességei alapján kerül egy-egy mintázati csoportba.

További problémája a jelenleg publikált globális kódolási eljárásoknak, hogy a fapofa-helyzetnek csak egyetlen szakasza (Reck és mtsai, 2009), vagy egy összevont, a teljes fapofa-helyzetre adott reakció alapján (Barbosa és mtsai, 2018) sorolják be a csecsemôket egy domináns mintázatba. Ez a fajta globális viselkedésmintázat alapú, ugyanakkor szelektív szempontra támaszkodó kategorizálás véleményünk szerint két nehézséget vet fel. Egyrészt nem tudja megragadni az egyes érzelmi és társas viselkedési összetevôk egyénre jellemzô szerepét a mintázatokon belül. Másrészt nem tudja vizsgálni a fapofa-helyzet egyes szakaszain belüli, valamint az egyes szakaszok közötti egyénre jellemzô változásokat. Ezáltal a viselkedés- és érzelmi mintázatok egyéni dinamikájának, valamint a helyzethez alkalmazkodó rugalmasságának, illetve rugalmatlanságának a felmérése ütközik akadályokba.

Bár számos kutatás vizsgálta a fapofa-helyzet egyes szakaszain belüli, illetve a szakaszok közötti különbségeket az affektivitás, a társas viselkedés és a diádikus összehangolódás terén (az összefoglalót lásd: Barbosa és mtsai, 2019; Mesman és mtsai, 2009; Tronick, 2007), e kutatások elsôsorban a viselkedések előfordulását vagy idôi mennyiségét hasonlították össze az egyes szakaszok között. Egyetlen kutatás sem vizsgálta ezzel szemben az egyénre, illetve párra jellemzô globális mintázatok változását a fapofa-helyzet szakaszai között.

\section{Kutatásunk célja}

A fentiekbôl kiindulva jelen kutatásban három fố célt tûztünk ki.

(1) Elsố lépésben egy olyan globális kódrendszer kialakitását céloztuk meg, amely a csecsemô érzelmi állapotának minôségét, továbbá a társas viselkedésének jellemzô mintázatát, valamint a stressz szintjének változását egymástól külön dimenziókban értékeli.

Jelen tanulmányban kizárólag a csecsemók viselkedésére és a fapofa-helyzet két szakaszára - a fapofa- és a regulációs szakaszokra -, valamint a két szakasz közötti változásokra koncentráltunk. A csecsemô anyától független viselkedésmintázatának értékelésére, illetve a fapofa-helyzet csak bizonyos szakaszainak elemzésére számos példát olvashatunk a szakirodalomban (lásd például Kogan és Carter, 1996; Coppola és mtsai, 2015; Ekas, Haltigan és Messinger, 2013; Giusti, Provenzi és Montirosso, 2018). Azért 
esett a választásunk e két szakasz értékelésére, mert a stressz aktivációja és regulációja szempontjából kritikus helyzetre jellemzô szabályozási sajátosságokat kívántuk megvizsgálni. Kérdésünk volt, hogy találunk-e az egyes szakaszokban jellemzô mintázatokat a csecsemó érzelmi állapotának szintje és a társas viselkedése szempontjából, és ha igen, ezek a mintázatok stabilak maradnak-e, vagy változnak a fapofa-szakaszról a regulációs szakaszra. Ez utóbbi kérdést a globális kódrendszerekkel dolgozó tanulmányok eddig még nem tették fel a fapofa-paradigmát alkalmazó kutatásokban.

(2) Az életkori stabilitásra, illetve a nemi különbségekre kapott ellentmondásos eredmények alapján feltettük a számunkra is nyitott kérdést, hogy találunk-e különbségeket a fiúk és a lányok, illetve a 3, a 4 és az 5 hónapos csecsemók között az általunk kialakított globális kódrendszerrel.

(3) A globális dimenziókra épüló kódrendszerekkel történô mintázatkeresés kifejezetten hiányterület a fapofa-vizsgálatokban (Barbosa és mtsai, 2018). Kutatásunkban ezért arra kerestünk választ, hogy az általunk kialakított globális kódrendszer dimenzióinak bevonásával kirajzolódnak-e jellemzô, a regulációs mintázatokat leíró fô klaszterek, és ha igen, azok létrejöttében mely dimenziók játszhatják a fő szerepet: az érzelmi szint, a társas viselkedés vagy a stressz-szint változása?

\section{MÓDSZEREK}

\section{Vizsgálati személyek}

Vizsgálatunkban 101 anya-gyermek páros vett részt, 54 fiúgyermek és 47 lány. A csecsemôk életkora 12-33 hetes kor között volt (átlagéletkor 19,63 hét, SD = 5,098). A nem és a kor alapján történt eloszlást az 1. táblázat mutatja. A csecsemók gesztációs ideje 38 és 42 hét között volt, normál súllyal születtek (2900 és 3800 gramm között), és tipikus fejlôdésû́ek voltak (egyikôjük sem rendelkezett eltérô fejlődés korai diagnózisával).

1. táblázat. A csecsemốk életkori adatai nemi bontásban

\begin{tabular}{lcc}
\hline & Fiú & Lány \\
\hline $\mathrm{N}$ & 54 & 47 \\
Életkor átlaga (hetekben) & 20,04 & 19,17 \\
Szórás & 5,154 & 4,993 \\
\hline
\end{tabular}

A vizsgálat menete

A családok a PPKE Pszichológiai Intézetének fejlődéspszichológiai vizsgálatokra kialakított Babalaborjába érkeztek. A klasszikus fapofa-paradigma (Face to Face Still Face, Tronick és munkatársai, 1978) 6 perces változatát alkalmaztuk, annak szigorított verzióját, amelyben az anya az interakciós helyzet alatt nem érinthette meg gyermekét. A csecsemót egy kényelmes babaszékben helyeztük el, az anyát vele szemben ültettük le úgy, hogy a csecsemó és az anya arca egy vonalban legyen. A teljes interakció alatt kettesben voltak a vizsgálóhelyiségben. A vizsgálatvezetố a szomszédos, detektívtükör- 
rel elválasztott megfigyelôhelyiségbốl kezelte a kamerát. Egy idôben három kameraállásból rögzítettük kettejük interakcióját. Egy-egy kamerával vettük a csecsemô arcát és teljes testét, illetve az anya arcát és felsôtestét. Egy harmadik kamera távolabbról készített felvételén az anya és a gyermek is teljes testtel volt látható. A kamerák egy számítógéphez csatlakoztak a detektívtükörrel elválasztott megfigyeloohelyiségben. A kétperces kötetlen interakció végén az anyának a detektívtükrön koppintással jeleztük, hogy vegyen fel egy semleges arcot, ne beszéljen, ne kommunikáljon, és maradjon mozdulatlan, de nézze gyermekét, hogy a gyermek lássa, ó jelen van és figyel. A fapofa-szakasz végén ismét koppintás jelezte az anyának, hogy ismét beszélhet gyermekéhez, és ha úgy érzi, hogy az elkeseredett, próbálja megnyugtatni szavakkal, és állítsa helyre a megszokott, kellemes interakciót. Az anyákat előzetesen tájékoztattuk arról, hogy bármikor megszakíthatják a helyzetet, ha úgy érzik, hogy a gyermeknek vagy nekik az megterhelö.

A helyzetet négyosztású képernyôn rögzítettük szimultán. Az elkészült felvételek visszajátszását a Shotcut videószerkesztô program 19.09.14-es verziójával végeztük, és a jelen kutatás céljára kialakított Érzelmi és Társas Szabályozási Mintázatok Globális Kódrendszerével értékeltük. A 101 anya-csecsemó párból 5 édesanya megszakította a vizsgálatot a fapofa-szakasz végén, ezért a regulációs szakasz és a két szakasz közti összefüggések elemzésében 96 anya-csecsemó páros szerepelt. További 6 anya lerövidítette a regulációs szakaszt. Az elemzésbe ezeket a felvételeket is bevontuk, és a rövidített szakaszt kódoltuk.

\section{Az Érzelmi és Társas Szabályozási Mintázatok Globális Kódrendszere}

Az Érzelmi és Társas Szabályozási Mintázatok Globális Kódrendszerét e kutatás céljaira dolgoztuk ki, elsô lépésben a fapofa-helyzet második és harmadik szakaszának (fapofa- és regulációs szakaszok) értékelésére. Célunk az volt, hogy a csecsemó érzelmi állapotát és az anyára irányuló társas viselkedését egymástól elkülönített két globális dimenzió mentén tudjuk értékelni, a helyzet mindkét szakaszában. A regulációs szakasz értékelését az említett két dimenzió mellett a stressz-szint változásának dimenziójával egészítettük ki. A kódrendszer felépítését és a dimenziókban szereplô kategóriáinak rövidített definícióit áttekintés céljából a 2. és a 3. táblázatban foglaltuk össze.

Az Érzelmi állapot dimenzióban a csecsemô szakaszra jellemzô domináns érzelmi állapotát kódoltuk az arckifejezés, a testhelyzet és a negatív, illetve a pozitív vokalizáció vagy annak hiánya együttes elófordulásának figyelembevételével, és függetlenül attól, hogy a csecsemố tekintete mire irányult. A három viselkedés (arckifejezés, testhelyzet és vokalizáció) alapján az érzelmi állapot három kategóriáját definiáltuk a nyugodttól a kiborult állapotig.

A Társas viselkedés dimenzióban az anya arcára és/vagy szemébe nézést, az eközben mutatott érzelemkifejezést (pozitív, negatív, semleges), valamint a vokalizációt (pozitív, negatív), illetve annak hiányát vettük figyelembe. A társas viselkedésnek természetesen ezenkívül még több más eleme is szerepet játszhat a kommunikációban, például a testhelyzettel, illetve kézmozdulatokkal kifejezett viselkedések (Murray és Trevarthen, 1985; Reck és mtsai, 2009, Tronick és mtsai, 1978). Jelen kódrendszerben azonban 
2. táblázat. Az Érzelmi és Társas Szabályozási Mintázatok Globális Kódrendszere, ${ }^{1}$ fapofa- (Still Face, SF) szakasz

\begin{tabular}{|c|c|c|}
\hline \multirow[t]{3}{*}{$\begin{array}{l}\text { Érzelmi állapot } \\
\text { (a teljes szakasz alatt) }\end{array}$} & Nyugodt & $\begin{array}{l}\text { A baba alapvetôen nyugodt marad a } 2 \text { perc } \\
\text { alatt. }\end{array}$ \\
\hline & Nyúgös & $\begin{array}{l}\text { Jelzi a stresszt, a kellemetlen érzést } \\
\text { vokalizációval is kifejezi. }\end{array}$ \\
\hline & Kiborul & Intenzív, elkeseredett, folyamatos sírás. \\
\hline \multirow[t]{6}{*}{$\begin{array}{l}\text { Anyára irányuló társas } \\
\text { viselkedés }\end{array}$} & Elkerüló & $\begin{array}{l}\text { A baba nem néz hosszabban az anya } \\
\text { arcába/szemébe. }\end{array}$ \\
\hline & Többnyire elkerülő & $\begin{array}{l}\text { Rövid anyára nézések előfordulnak, de a } \\
\text { szakaszban dominánsabb az elkerülés. }\end{array}$ \\
\hline & Anyára semleges & $\begin{array}{l}\text { Anya szemébe/arcára néz hosszasan, } \\
\text { közben arckifejezése semleges. }\end{array}$ \\
\hline & Anyára pozitív & $\begin{array}{l}\text { Anya szemébe/arcára néz, közben } \\
\text { arckifejezése pozitív érzelmet mutat. }\end{array}$ \\
\hline & Anyára negatív & $\begin{array}{l}\text { Anya szemébe/arcára néz, miközben } \\
\text { negatív érzelmi arckifejezése van. }\end{array}$ \\
\hline & Anyára vegyes & $\begin{array}{l}\text { Pozitív és negatív anyára nézés egyaránt } \\
\text { elôfordul/váltakozik a szakaszban. }\end{array}$ \\
\hline
\end{tabular}

3. táblázat. Az Érzelmi és Társas Szabályozási Mintázatok Globális Kódrendszere, regulációs szakasz

\begin{tabular}{|c|c|c|}
\hline \multirow[t]{2}{*}{$\begin{array}{l}\text { Érzelmi állapot } \\
\text { a szakasz elején } \\
\text { (a szakasz elsó } 30 \\
\text { másodpercében) }\end{array}$} & Nyugodt & $\begin{array}{l}\text { A baba alapvetôen nyugodt a szakasz } \\
\text { elején. }\end{array}$ \\
\hline & Kiborul & Intenzív, elkeseredett, folyamatos sírás. \\
\hline \multirow[t]{5}{*}{ Stressz-szint változása } & Nyugodt-nyugodt & $\begin{array}{l}\text { A baba nyugodt a szakasz elején, és } \\
\text { nyugodt is marad a regulációs szakaszban. }\end{array}$ \\
\hline & Nyugodt-pozitív & $\begin{array}{l}\text { A baba nyugodt a szakasz elején, majd a } \\
\text { szakasz végére pozitívabb érzelmi állapotba } \\
\text { kerül. }\end{array}$ \\
\hline & Stressz csökkenése & $\begin{array}{l}\text { A szakasz elején nyúgös vagy kiborult } \\
\text { állapotban van, de a stressz-szintje csökken } \\
\text { a szakaszban. }\end{array}$ \\
\hline & Stressz eszkalálódása & $\begin{array}{l}\text { A szakasz elejéhez képest a baba nyúgösebb } \\
\text { állapotba kerül, vagy kiborul. }\end{array}$ \\
\hline & Stressz-szint állandó & $\begin{array}{l}\text { A stressz-szint a szakasz elejétôl a végéig } \\
\text { stagnál. }\end{array}$ \\
\hline
\end{tabular}

A 2. és a 3. táblázat csupán a kódrendszer pontjainak vázlatos áttekintését és azok rövidített definícióit tartalmazza. A részletes kódrendszer a dimenziók kategóriáinak pontos definíciójával, valamint részletes viselkedéses és idôtartambeli kritériumaival elérhetô Hámori Eszternél. 
3. táblázat folyt.

\begin{tabular}{lll}
\hline $\begin{array}{l}\text { Anyára irányuló társas } \\
\text { viselkedés }\end{array}$ & Elkerülố & $\begin{array}{l}\text { A baba nem néz hosszabban az anya } \\
\text { arcába/szemébe. }\end{array}$ \\
& Többnyire elkerülố & $\begin{array}{l}\text { Rövid anyára nézések elófordulnak, de a } \\
\text { szakaszban dominánsabb az elkerülés. }\end{array}$ \\
Anyára semleges & $\begin{array}{l}\text { Anya szemébe/arcára néz hosszasan, } \\
\text { közben arckifejezése semleges. }\end{array}$ \\
Anyára pozitív & $\begin{array}{l}\text { Anya szemébe/arcára néz, közben } \\
\text { arckifejezése pozitív érzelmet mutat. }\end{array}$ \\
Anyára negatív & $\begin{array}{l}\text { Anya szemébe/arcára néz, miközben } \\
\text { érzelmi arckifejezése negatív. }\end{array}$ \\
Anyára vegyes & $\begin{array}{l}\text { Pozitív és negatív anyára nézés egyaránt } \\
\text { elôfordul/váltakozik a szakaszban. }\end{array}$ \\
\hline
\end{tabular}

csak a fent leírt három viselkedés együtt járását és konfigurációit vettük figyelembe, ezek kiemelt kommunikációs üzenetértéke miatt (Tronick, 2007). A fapofa-helyzet elemzésére kialakított viselkedéses konfigurációk hasonló szelekciója nem szokatlan az egyes kutatásokban. Így például Ekas és munkatársai (2013) csak az anyára tekintést és ez ehhez társuló érzelemkifejezést kódolták az ún. regulációs profil felrajzolásakor, a vokalizációt és a testhelyzetet nem vették figyelembe. Bigelow és munkatársai (2018) kutatásukban ezzel szemben a tekintet iránya mellett a vokalizáció minőségét is figyelembe vették a társas kezdeményezés mintázatainak felmérésében.

A Stressz-szint változása dimenzióban a csecsemố stressz-szintjének alakulását jellemeztük a regulációs szakasz elején mutatott érzelmi állapotához képest, a szakasz végéig. A stressz-szint viselkedéses megjelenése és szintjének alakulása (csökkenése, növekedése, stagnálása) idổi és intenzitásbeli változatosságot mutathat, akár egyetlen baba esetében is (lásd pl. Ekas, Haltigan és Messinger, 2013). Jelen esetben ezeket a dinamikus paramétereket nem differenciáltuk, csupán az intenzitás változásának irányát figyeltük meg.

Kódrendszerünk további jellemzője, hogy az egyes dimenziókban szereplố kategóriákhoz pontos viselkedésleírás tartozik, továbbá ahol szükséges, pontos idối kritériumokat határoztunk meg. ${ }^{2}$ Az egyes kategóriákhoz tartozó viselkedéses konfigurációkat, valamint ezek idói feltételeit és megkötéseit a fapofa-helyzettel dolgozó kutatások tapasztalatai alapján definiáltuk és szabtuk meg (lásd például Ekas és mtsai, 2013; Bigelow és mtsai, 2018; Montirosso és mtsai, 2015; Tronick, 2007; Tronick és mtsai, 1978).

Mivel a kódrendszerünk globálisan írja le az adott szakaszban a csecsemố dominánsan jellemzó érzelmi állapotát, illetve a társas viselkedését, továbbá a regulációs szakaszban a stressz szintjének változását, ezért mindegyik dimenzióban egy-egy kód adható a szakaszra vonatkozóan.

2 A pontos definíciókat és kritériumokat tartalmazó részletes kódrendszer elérhetô Hámori Eszternél. 


\section{A kódrendszer megbízhatósága}

Kódrendszerünk megbízhatóságát a minta 15\%-án végzett kontroll kódolásával ellenôriztük. A 15\%-os kontroll kódolási arányt a fapofa-helyzettel dolgozó idôsoros, valamint a globális kódrendszereket alkalmazó, illetve azokat kifejlesztô kutatások módszertani gyakorlata alapján választottuk (lásd például Bigelow és Power, 2016; MacLean, Rynes, Aragón, Caprihan, Phillips és Lowe, 2014; Provenzi, Olson, Montirosso és Tronick, 2016; Li és mtsai, 2019). Dimenziókra bontva vizsgáltuk a független kódolók egyetértésének mértékét. A $\kappa$ értékek minden esetben az elfogadhatónak számító 0,6-es kritérium érték felett (lásd pl. Ekas és mtsai, 2013) helyezkedtek el (4. táblázat). Kiemelkedő egyetértés mutatkozott az érzelmi dimenzióban, illetve a stressz-szint változásának megítélésében. A társas dimenzió kódolásában jelentek meg a legnagyobb különbségek mindkét szakaszban. A kódolók közti egyetértés a definíciók pontosítását és a kódrendszer javítását követôen a megfelelô megbízhatósági tartományba növekedett.

4. táblázat. A kódolók közti egyetértés mértéke dimenziók szerint

\begin{tabular}{ll}
\hline Dimenziók & $\kappa$ \\
\hline Érzelmi állapot az SF szakaszban & 0,877 \\
Anyára irányuló társas viselkedés az SF szakaszban & 0,676 \\
Érzelmi állapot a regulációs szakaszban & 1 \\
Stressz-szint változása a regulációs szakaszban & 0,889 \\
Anyára irányuló társas viselkedés a regulációs szakaszban & 0,623 \\
\hline
\end{tabular}

\section{Az adatok statisztikai elemzése}

A változóink a csecsemôk életkorát leszámítva kategorikus (az anyára irányuló társas viselkedés, valamint a stressz-szint változása) vagy ordinális (érzelmi állapot) természetûek voltak, ezért az esetek többségében nem parametrikus statisztikai próbákat végeztünk. A fapofa-helyzet két szakaszát leíró statisztikákkal és kereszttáblákkal jellemeztük, a nemek és a korcsoportok közti különbségeket $\chi^{2}$ próbával vizsgáltuk. Amikor nem teljesült a Pearson-féle $\chi^{2}$ próba feltétele, akkor a valószínúségi hányados (Likelihood ratio) segítségével következtettünk. A fapofa- és a regulációs szakasz közötti változásokat szintén kereszttáblával és valószínúségi hányadossal vizsgáltuk. A fapofa- és a regulációs szakasz érzelmi állapotai közti összefüggés vizsgálatára Spearman-féle korrelációs próbát végeztünk. Az átcsapás jelenségét (Mesman és mtsai, 2009) kereszttábla segítségével követtük nyomon. Az anyára irányuló társas viselkedés alakulását szintén valószínúségi hányadossal vizsgáltuk. Végül kétlépcsôs klaszteranalízissel (Two-step Cluster Analysis) vizsgáltuk meg, hogy a két szakasz dimenziói, valamint az életkor és a nem bevonásával a csecsemók hány csoportja különül el. Az adataink vizsgálatát az IBM SPSS statisztikai program 22. verziójával végeztük. 
A vizsgálat a Pázmány Péter Katolikus Egyetem Pszichológiai Intézetének Korai Fejlôdés és Kötôdés Kutatómúhelye által vezetett Kisgyermekkori regulációs zavarok genetikai és epigenetikai hátterẻ címú kutatás részeként zajlott. Az adatfelvétel 2017 májusától 2019 júliusáig tartott. A szülôi tájékoztatás, az adatfelvétel és az adattárolás, illetve az adatok feldolgozása az adatvédelmi törvényeknek megfelelôen és etikai engedélyezéssel zajlott (Etikai engedély száma: ETT-TUKEB 12775-1/2017/EKU).

\section{EREDMÉNYEK}

\section{A fapofa- (Still Face) szakasz}

A fapofa-szakaszban két dimenzió mentén, az érzelmi állapot és az anyára irányuló társas viselkedés alapján jellemeztük a csecsemôket. Az anyára irányuló társas viselkedések eredetileg hat kategóriáját (2. és 3. táblázat) négy kategóriára redukáltuk. Az Elkerüló, a Többnyire elkerüló és az Anyára semleges kategóriákat a kategóriák alacsony elemszáma miatt összevontuk, és Minimalizáló néven egy csoportként kezeltük (5. táblázat). Azért döntöttünk az összevonhatóság és az elnevezés mellett, mert az elkerülố és a semleges viselkedés esetében egyaránt megjelenik az anyával való érzelemmel teli kontaktus, illetve a kommunikációs szándék minimalizálása (Kogan és Carter, 1996; Reck és mtsai, 2009; Tronick, 2007). Az Elkerülônél és a Többnyire elkerülónél (2. és 3. táblázat) az anyára nézés, míg a Semlegesnél a pozitív és a negatív érzelemkifejezés minimalizálása volt domináns. A minta eloszlása a százalékos aránnyal és a nemekkel az 5. táblázatban látható.

Az életkori különbségek vizsgálatára három korcsoportot képeztünk a teljes mintán. Az elsố csoportba azokat a csecsemôket soroltuk, akik elmúltak három hónaposak, de még nem töltötték be a negyedik hónapot. A második csoportba négytôl öt hónapos korig, a harmadik csoportba az öt hónapnál idôsebb csecsemôk kerültek. A három korcsoport fapofa-szakaszban mutatott érzelmi állapotának, illetve anyára irányuló társas viselkedésének eloszlását a 6. táblázat foglalja össze.

A nemi különbségek vizsgálatakor a Pearson-féle $\chi^{2}$ próba eredménye sem az érzelmi állapot minôségében $\left\{\chi^{2}([2] \mathrm{N}=[101])=0,781 ; \mathrm{p}=0,677\right.$ (2-tailed) $\left.\mathrm{V}=0,088\right\}$, sem pedig az anyára irányuló társas viselkedésben nem mutatott szignifikáns eltérést $\left\{\chi^{2}([3] \mathrm{N}=[101])=0,857 ; \mathrm{p}=0,836\right.$ (2-tailed) $\left.\mathrm{V}=0,092\right\}$. Azaz a fiúknál és a lányoknál azonos arányban jelent meg a nyugodt, a nyúgös és a kiborult állapot, továbbá a minimalizáló, az anyára pozitív, az anyára negatív és az anyára vegyes társas viselkedés. A korcsoportok közötti különbségek valószínúségi hányadossal való vizsgálatakor nem volt kimutatható különbség sem az érzelmi állapotok minôségében $\left\{\chi^{2}([4] \mathrm{N}=[101])\right.$ $=2,768 ; \mathrm{p}=0,597$ (2-tailed) $\mathrm{V}=0,115\}$, sem a társas viselkedésben $\left\{\chi^{2}([6] \mathrm{N}=[101])\right.$ $=4,442 ; \mathrm{p}=0,617$ (2-tailed) $\mathrm{V}=0,149\}$.

A kutatást a PPKE KAP16-71044-1.1-BTK és a KAP17-61001-1.1-BTK pályázatai támogatták. Kutatásvezetôk: Hámori Eszter, Barta Csaba. 
5. táblázat. Az érzelmi állapot és az anyára irányuló társas viselkedés eloszlása a teljes mintán nemek szerint a fapofa-szakaszban

\begin{tabular}{llccrr}
\hline & & \multirow{2}{*}{$\mathrm{N}$} & $\%$ & Fiú & Lány \\
& & & & $\mathrm{N}=54$ & $\mathrm{~N}=47$ \\
\hline \multirow{3}{*}{ Érzelmi állapot } & Nyugodt & 54 & $53,46 \%$ & 31 & 23 \\
& Nyúgös & 34 & $33,66 \%$ & 7 & 17 \\
& Kiborul & 13 & $12,87 \%$ & 6 & 7 \\
\hline \multirow{4}{*}{ Anyára irányuló } & Minimalizáló & 15 & $14,85 \%$ & 8 & 7 \\
társas viselkedés & Anyára pozitív & 29 & $28,71 \%$ & 15 & 14 \\
& Anyára negatív & 27 & $26,73 \%$ & 13 & 14 \\
& Anyára vegyes & 30 & $29,7 \%$ & 18 & 12 \\
\hline
\end{tabular}

6. táblázat. Az érzelmi állapot és az anyára irányuló társas viselkedés eloszlása a fapofa-szakaszban, korcsoportok alapján

\begin{tabular}{llccc}
\hline & & $\begin{array}{c}\text { 1. korcsoport } \\
\mathrm{N}=29\end{array}$ & $\begin{array}{c}\text { 2. korcsoport } \\
\mathrm{N}=32\end{array}$ & $\begin{array}{c}\text { 3. korcsoport } \\
\mathrm{N}=40\end{array}$ \\
\hline \multirow{3}{*}{ Érzelmi állapot } & Nyugodt & 17 & 15 & 22 \\
& Nyúgös & 8 & 11 & 15 \\
& Kiborul & 4 & 6 & 3 \\
\hline \multirow{4}{*}{ Anyára irányuló } & Minimalizáló & 7 & 3 & 5 \\
társas viselkedés & Anyára pozitív & 7 & 10 & 12 \\
& Anyára negatív & 5 & 10 & 12 \\
& Vegyes stratégia & 10 & 9 & 11 \\
\hline
\end{tabular}

\section{A regulációs szakasz}

A mintánk elemszáma ebben a szakaszban $(\mathrm{N}=96)$ eltért a korábbi elemszámtól $(\mathrm{N}=101)$, mivel 5 gyermek esetében az anya megszakította a vizsgálatot. A regulációs szakaszban az érzelmi állapot és az anyára irányuló társas viselkedés mellett a csecsemôk stressz-szintjének alakulását is megvizsgáltuk. A kódrendszerünk stressz-szint-változás dimenziójában szereplô öt kategóriát (3. táblázat) három kategóriába vontuk össze (7. táblázat) az egyes csoportokba tartozó elemszám növelése és a stressz-szint változásának kezelhetôbb kategóriaszáma miatt. Ez alapján az elsô csoportba azok a csecsemók kerültek, akik a regulációs szakasz elején nyugodtak voltak, és nyugodtak is maradtak, esetenként pozitívvá váltak a regulációs szakasz végére (összevont kategória: stressz nem mutatkozott). A második csoportba azok a csecsemók kerültek, akik a regulációs szakasz elején kifejezték a stresszt, stressz-szintjük azonban a szakasz végére csökkenô tendenciát mutatott. Végül a harmadik csoportba azok a csecsemók tartoztak, akiknél a regulációs szakasz elején a stressz szintén megjelent, és a stressz-szint a szakasz végéig stagnált vagy emelkedett (összevont kategória: a stressz-szint állandó / növekszik). A regulációs szakaszban mutatott érzelmi állapot, az anyára irányuló társas viselkedés és a stressz-szint alakulásának mintára jellemzó eloszlását a 7. táblázatban foglaltuk össze a teljes minta és a nemi eloszlások feltüntetésével. 
7. táblázat. Érzelmi állapot, anyára irányuló társas viselkedés és a stressz-szint alakulása a regulációs szakaszban a teljes mintán nemek szerint

\begin{tabular}{|c|c|c|c|c|c|}
\hline & & $\mathrm{N}$ & $\%$ & $\begin{array}{c}\text { Fiú } \\
N=51\end{array}$ & $\begin{array}{l}\text { Lány } \\
\mathrm{N}=45\end{array}$ \\
\hline \multirow{3}{*}{$\begin{array}{l}\text { Érzelmi állapot } \\
\text { szakasz elején } \\
(30 \mathrm{mp})\end{array}$} & Nyugodt & 60 & $62,5 \%$ & 35 & 25 \\
\hline & Nyúgös & 24 & $25 \%$ & 11 & 13 \\
\hline & Kiborul & 12 & $12,5 \%$ & 5 & 7 \\
\hline \multirow{4}{*}{$\begin{array}{l}\text { Anyára irányuló } \\
\text { társas viselkedés } \\
\text { (teljes szakasz) }\end{array}$} & Minimalizáló & 5 & $5,2 \%$ & 1 & 4 \\
\hline & Anyára pozitív & 47 & $48,95 \%$ & 27 & 20 \\
\hline & Anyára negatív & 13 & $13,54 \%$ & 6 & 7 \\
\hline & Anyára vegyes & 31 & $32,29 \%$ & 17 & 14 \\
\hline \multirow{3}{*}{$\begin{array}{l}\text { Stressz-szint alakulása } \\
\text { (a szakasz elejének } \\
\text { érzelmi állapotához } \\
\text { képest) }\end{array}$} & Stressz nem mutatkozik & 54 & $56,25 \%$ & 30 & 24 \\
\hline & Stressz-szint csökken & 19 & $19,79 \%$ & 9 & 10 \\
\hline & $\begin{array}{l}\text { Stressz-szint állandó / } \\
\text { növekszik }\end{array}$ & 23 & $23,95 \%$ & 12 & 11 \\
\hline
\end{tabular}

A Pearson-féle $\chi^{2}$ próba alapján az érzelmi állapot $\left\{\chi^{2}([2] \mathrm{N}=[96])=1,799\right.$; $\mathrm{p}=0,407$ (2-tailed) $\mathrm{V}=0,137\}$ és a stressz-szint alakulása $\left\{\chi^{2}([2] \mathrm{N}=[96])=0,389\right.$; $\mathrm{p}=0,823$ (2-tailed) $\mathrm{V}=0,064\}$ nem mutatott szignifikáns eltérést a fiúk és a lányok között. Ehhez hasonlóan a valószínúségi hányadost alkalmazva a társas viselkedésben sem jelent meg szignifikáns nemi különbség $\left\{\chi^{2}([3] \mathrm{N}=[96])=2,966 ; \mathrm{p}=0,397\right.$ (2-tailed) $\mathrm{V}=0,172\}$.

A korcsoportok (8. táblázat) között nem volt szignifikáns különbség az érzelmi állapotban $\left\{\chi^{2}([4] \mathrm{N}=[96])=4,679 ; \mathrm{p}=0,322\right.$ (2-tailed) $\left.\mathrm{V}=0,150\right\}$, az anyára irányuló társas viselkedésben $\left\{\chi^{2}([6] \mathrm{N}=[96])=6,351 ; \mathrm{p}=0,385\right.$ (2-tailed) $\left.\mathrm{V}=0,178\right\}$, és a stressz-szint alakulásában sem $\left\{\chi^{2}([4] \mathrm{N}=[96])=6,170 ; \mathrm{p}=0,187\right.$ (2-tailed) $\mathrm{V}=0,179\}$.

8. táblázat. Érzelmi állapot, anyára irányuló társas viselkedés és a stressz-szint alakulása a regulációs szakaszban az életkori csoportok szerint

\begin{tabular}{|c|c|c|c|c|}
\hline & & $\begin{array}{c}1 . \\
\text { korcsoport } \\
\mathrm{N}=26\end{array}$ & $\begin{array}{c}2 . \\
\text { korcsoport } \\
\mathrm{N}=31\end{array}$ & $\begin{array}{c}3 . \\
\text { korcsoport } \\
\mathrm{N}=39\end{array}$ \\
\hline \multirow{3}{*}{$\begin{array}{l}\text { Érzelmi állapot a } \\
\text { szakasz elején }\end{array}$} & Nyugodt & 20 & 19 & 21 \\
\hline & Nyúgös & 3 & 8 & 13 \\
\hline & Kiborul & 3 & 4 & 5 \\
\hline \multirow{4}{*}{$\begin{array}{l}\text { Anyára irányuló társas } \\
\text { viselkedés }\end{array}$} & Minimalizáló & 2 & 2 & 1 \\
\hline & Anyára pozitív & 17 & 14 & 16 \\
\hline & Anyára negatív & 2 & 4 & 7 \\
\hline & Anyára vegyes & 5 & 11 & 15 \\
\hline \multirow{3}{*}{ Stressz-szint alakulása } & Stressz nem mutatkozott & 13 & 18 & 17 \\
\hline & Stressz-szint csökkenése & 3 & 7 & 9 \\
\hline & $\begin{array}{l}\text { Stressz-szint állandó / } \\
\text { növekedése }\end{array}$ & 4 & 6 & 13 \\
\hline
\end{tabular}


A két szakasz érzelmi állapot dimenziója közti összefüggés vizsgálatára Spearman-féle korrelációt alkalmaztunk. Az eredmény alapján pozitív, erôs kapcsolat áll fent a két szakasz érzelmi állapotai között $\left\{\mathrm{r}_{\mathrm{s}}=0,793 ; \mathrm{p}<0,01\right.$ (1-tailed) $\}$. A magas korreláció egyrészt jelzi, hogy a fapofa-szakaszban jellemzó érzelmi állapotot a csecsemók egy része a regulációs szakasz elejére is átviszi, így az idôi folytonosságot nézve eredményünk nem meglepó. Ugyanakkor a korrelációs együttható nem éri el a 0,800 értéket, ami arról informál, hogy vannak csecsemók, akik az anya újbóli interakcióba lépésekor érzelmi állapotot váltanak, azaz a fapofa-helyzet alatt jellemzó állapotból egy másik állapotba kerülnek már rögtön a szakasz elején.

Ahhoz, hogy részletesebben vizsgálhassuk, hogy a csecsemôk a fapofa-szakaszban domináns érzelmi állapotukból milyen érzelmi állapotba kerültek a regulációs szakasz elejére, létrehoztunk egy új változót, amelyben csoportosítottuk a változás lehetséges irányait. A kilenc lehetôségbôl mintánkon csak hét jelent meg (9. táblázat). Nem volt ugyanis példa olyan gyermekre, aki a fapofa-szakaszban nyugodt volt, és a regulációs szakasz elején kiborult volna, illetve nem fordult elô, hogy a fapofa-szakaszban kiborult állapotban lévô csecsemôk a regulációs szakasz elején hirtelen megnyugodtak volna. A változás irányát jelzô kategóriákon belüli elemszámokat a hozzájuk tartozó százalékértékekkel a 9. táblázat foglalja össze.

9. táblázat. Az érzelmi állapot változása a fapofa-szakaszról a regulációs szakaszra

\begin{tabular}{lrr}
\hline & \multicolumn{1}{c}{$\mathrm{N}$} & \multicolumn{1}{c}{$\%$} \\
\hline Nyugodt-nyugodt & 51 & $53,1 \%$ \\
Nyugodt-nyúgös & $\mathbf{3}$ & $3,1 \%$ \\
Nyúgös-nyugodt & 9 & $9,4 \%$ \\
Nyúgös-nyúgös & 20 & $20,8 \%$ \\
Nyúgös-kiborul & $\mathbf{4}$ & $4,2 \%$ \\
Kiborul-nyúgös & 1 & $1 \%$ \\
Kiborul-kiborul & 8 & $8,3 \%$ \\
\hline
\end{tabular}

A 9. táblázatból látható, hogy összesen 3 olyan csecsemó volt, aki a fapofa-szakasz alatti nyugodt állapotot követôen a regulációs szakasz elején nyúgösködött, illetve 4 olyan gyermek volt, aki a fapofa-szakaszban nyúgösködött, és a regulációs szakasz elején az anya interakcióba lépésekor kiborult. A változás irányát jelzố új változó alapján a szakirodalomban átcsapásnak (Mesman és mtsai, 2009) nevezett jelenség mintánkon tehát összesen 7 csecsemônél jelent meg (9. táblázat, félkövérrel kiemelve).

\section{Az anyára irányuló társas viselkedés változása a fapofa-szakaszról a regulációs szakaszra}

Kereszttábla segítségével megnéztük, hogyan alakul a csecsemôk társas viselkedése a fapofa-szakaszról a regulációs szakaszra (10. táblázat). A 16 lehetséges variáció közül 
mintánkon csak 12 jelent meg (10. táblázat). Nem volt ugyanis példa arra, hogy a fapofa-szakaszban dominánsan anyára negatív társas viselkedést a regulációs szakaszban dominánsan anyára pozitív váltsa fel. Arra sem volt példa, hogy a fapofa-szakaszban domináns minimalizáló viselkedést anyára negatív váltsa fel a regulációs szakaszban. Továbbá, a fapofa-szakaszban dominánsan anyára pozitív, illetve anyára vegyes társas viselkedést sem követte minimalizáló viselkedés a regulációs szakaszban.

10. táblázat. A csecsemôk társas viselkedésének változása a két szakasz között

\begin{tabular}{|c|c|c|c|c|c|}
\hline \multicolumn{6}{|c|}{ Regulációs szakaszban mutatott társas viselkedés } \\
\hline \multirow{5}{*}{$\begin{array}{l}\text { A fapofa-szakaszban } \\
\text { mutatott társas } \\
\text { viselkedés }\end{array}$} & & $\begin{array}{l}\text { Minimalizáló } \\
\mathrm{N}=5\end{array}$ & $\begin{array}{l}\text { Anyára } \\
\text { pozitív } \\
\mathrm{N}=47\end{array}$ & $\begin{array}{l}\text { Anyára } \\
\text { negatív } \\
\mathrm{N}=13\end{array}$ & $\begin{array}{c}\text { Anyára } \\
\text { vegyes } \\
\mathrm{N}=31\end{array}$ \\
\hline & $\begin{array}{l}\text { Minimalizáló } \\
N=15\end{array}$ & $\begin{array}{c}2 \\
(\sim 13 \%)\end{array}$ & $\begin{array}{c}10 \\
(\sim 67 \%)\end{array}$ & 0 & $\begin{array}{c}3 \\
(20 \%)\end{array}$ \\
\hline & $\begin{array}{l}\text { Anyára } \\
\text { pozitív } \\
\mathrm{N}=29\end{array}$ & 0 & $\begin{array}{c}25 \\
(\sim 86 \%)\end{array}$ & $\begin{array}{c}1 \\
(\sim 3 \%)\end{array}$ & $\begin{array}{c}3 \\
(\sim 10 \%)\end{array}$ \\
\hline & $\begin{array}{l}\text { Anyára } \\
\text { negatív } \\
\mathrm{N}=23\end{array}$ & $\begin{array}{c}3 \\
(\sim 13 \%)\end{array}$ & 0 & $\begin{array}{c}9 \\
(\sim 39 \%)\end{array}$ & $\begin{array}{c}11 \\
(\sim 48 \%)\end{array}$ \\
\hline & $\begin{array}{l}\text { Anyára } \\
\text { vegyes } \\
\mathrm{N}=29\end{array}$ & 0 & $\begin{array}{c}12 \\
(\sim 41 \%)\end{array}$ & $\begin{array}{c}3 \\
(\sim 10 \%)\end{array}$ & $\begin{array}{c}14 \\
(\sim 48 \%)\end{array}$ \\
\hline
\end{tabular}

A domináns társas viselkedés változásának erôsségét valószínûségi hányados segítségével vizsgáltuk meg. A szakaszok között szignifikáns különbség mutatkozott $\left\{\chi^{2}\right.$ ([9] $\mathrm{N}=$ $[96])=64,640 ; \mathrm{p}<0,05$ (2-tailed) $\mathrm{V}=0,429\}$, ami jelzi, hogy a fapofa-szakasz domináns társas mintázatából több esetben is bejósolható a regulációs szakasz domináns társas viselkedése. A mintázatok alakulási irányát az 1. ábrán szemléltetjük.

Az 1. ábrán a vonalak vastagsága a stratégiák két szakasz közötti változásának, illetve változatlanságának 10. táblázatban látható elôfordulási gyakoriságát szemlélteti. A folyamatos vastag nyíl a szignifikáns kapcsolatot mutatja $\left\{\chi^{2}([9] \mathrm{N}=[96])=64,640\right.$; $\mathrm{p}<0,05$ (2-tailed) $\mathrm{V}=0,429\}$. Eszerint, az esélyhányadosok alapján négyszer nagyobb az esélye $[O R=(10 / 5) /(5 / 10)]$ annak, hogy a fapofa-szakaszban minimalizáló viselkedést anyára pozitív váltsa fel a regulációs szakaszban, mint hogy a csecsemô ettôl eltérố mintázatot kövessen. 39-szer nagyobb az esélye $[O R=(25$ / 4) / (4 / 25)], hogy a fapofa-szakaszban anyára pozitív csecsemók nem váltanak, és a regulációs szakaszban is anyára pozitív viselkedést mutatnak, mint hogy ettôl eltérjenek. A további változások esetében a $\chi^{2}$ próba nem mutatott szignifikáns különbséget a társas viselkedés mintázatának változási irányában. Ennek ellenére a nem szignifikáns irányokat is feltüntettük az 1. ábrán, mivel ezek olyan, az egyéni változatosság szélesebb spektrumát jelzô mintázatokról informálhatnak, amelyeket egy nagyobb elemszámú mintán érdemes lehet tovább vizsgálni.

Az anyára irányuló társas viselkedésnek a fapofa-szakaszról a regulációs szakaszra történô változása (10. táblázat) mentén létrehoztunk egy új változót, amelyben magukat 


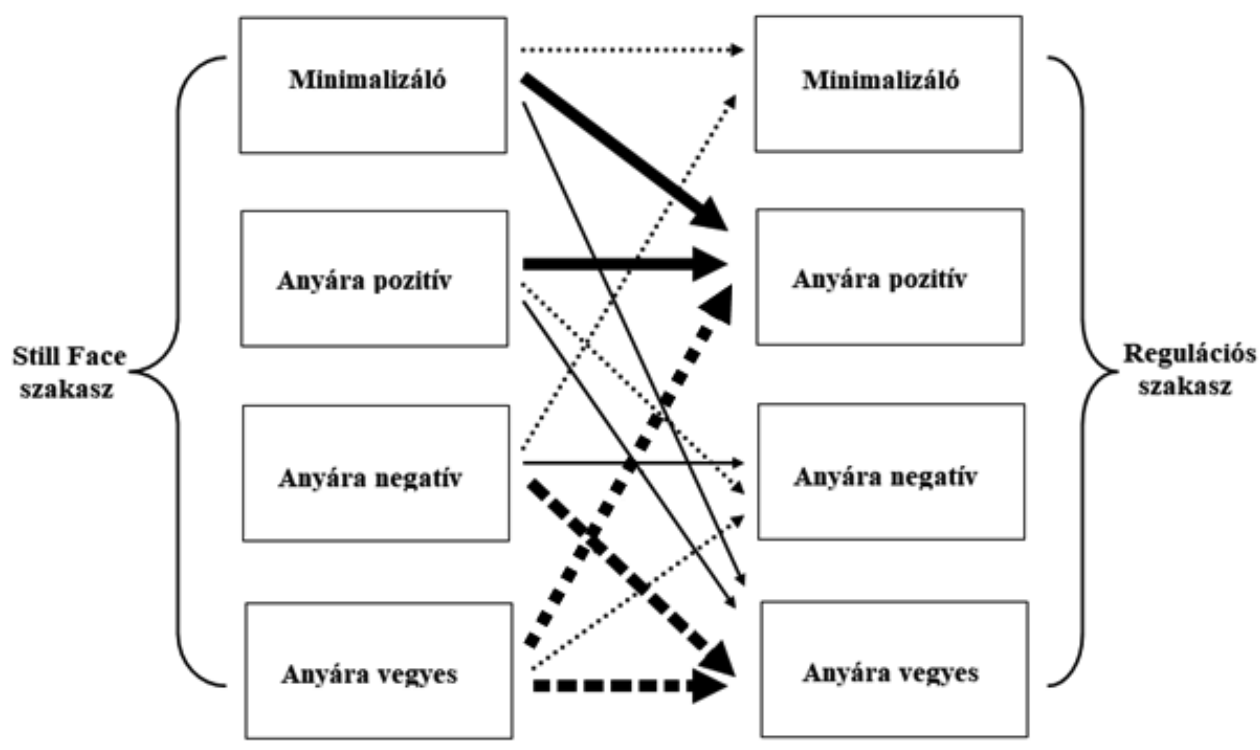

1. ábra. A társas viselkedés változásának iránya a fapofa- (Still Face) szakaszról a regulációs szakaszra

Megjegyzés:

$\longrightarrow$ szignifikáns változás (60\% feletti elöfordulás)

$--\rightarrow 60-40 \%$ közötti elöfordulás

$\rightarrow$ 40-20\% közötti elöfordulás

- 20\% alatti elöfordulás

a változásokat csoportosítottuk. Az új változót csak azokra a változási irányokra hoztuk létre, amely irányok esetében az elemszám meghaladta az 5 fớt. Így a következô elemzésbe összesen hat olyan változási irányt vontunk be (11. táblázat), amely változási irányok csoportjában az elemszám megfelelô volt a $\chi^{2}$ próba elvégzéséhez. Az összevont változó segítségével megvizsgáltuk, hogy a csecsemôk stressz-szintjében mutatkozik-e különbség aszerint, hogy hogyan alakult az anyára irányuló társas viselkedésük a fapofa-szakaszról a regulációs szakaszra. A valószínúségi hányados szignifikáns $\left[\chi^{2}\right.$ ([22] $\mathrm{N}=[96])=110,197 ; \mathrm{p}<0,05$ (2-tailed) $\mathrm{V}=0,749]$, tehát az anyára irányuló társas viselkedés két szakasz közötti változása több esetben is bejósolta a stressz-szint alakulását a regulációs szakaszban. A 11. táblázatban csak a magasabb elemszámmal rendelkezó hat változási csoport stressz-szintjének alakulását mutatjuk be.

A 11. táblázatból látható, hogy azoknál a csecsemóknél, akik mindkét szakaszban anyára pozitív társas viselkedést mutattak, 96\%-ban nem mutatkozott stressz a regulációs szakaszban. A fapofa- és a regulációs szakaszban egyaránt anyára negatív társas viselkedésú csecsemôk 100\%-ánál a stressz-szint növekedett, vagy állandóan magas 
11. táblázat. A társas viselkedés változása/változatlansága és a stressz-szint alakulása a regulációs szakaszban

\begin{tabular}{|c|c|c|c|c|}
\hline \multicolumn{5}{|c|}{ Stressz-szint változása a regulációs szakaszban } \\
\hline \multirow{7}{*}{$\begin{array}{l}\text { Az anyára irányuló } \\
\text { társas viselkedés } \\
\text { változásának iránya } \\
\text { a fapofa-szakaszról a } \\
\text { regulációs szakaszokra }\end{array}$} & & $\begin{array}{l}\text { Stressz nem } \\
\text { mutatkozott }\end{array}$ & $\begin{array}{l}\text { Stressz-szint } \\
\text { csökkenése }\end{array}$ & $\begin{array}{l}\text { Stressz-szint } \\
\text { állandó/ } \\
\text { növekedése }\end{array}$ \\
\hline & $\begin{array}{l}\text { Pozitív-pozitív } \\
\mathrm{N}=25\end{array}$ & $24 \uparrow$ & $0 \downarrow$ & $1 \downarrow$ \\
\hline & $\begin{array}{l}\text { Negatív-negatív } \\
\mathrm{N}=9\end{array}$ & $0 \downarrow$ & 0 & $9 \uparrow$ \\
\hline & $\begin{array}{l}\text { Negatív-vegyes } \\
\mathrm{N}=11\end{array}$ & $1 \downarrow$ & $9 \uparrow$ & 1 \\
\hline & $\begin{array}{l}\text { Vegyes-pozitív } \\
\mathrm{N}=12\end{array}$ & $12 \uparrow$ & $0 \downarrow$ & $0 \downarrow$ \\
\hline & $\begin{array}{l}\text { Vegyes-vegyes } \\
\mathrm{N}=14\end{array}$ & $4 \downarrow$ & $5 \uparrow$ & $5 \uparrow$ \\
\hline & $\begin{array}{l}\text { Minimalizáló-pozitív } \\
\mathrm{N}=10\end{array}$ & $\mathbf{8} \uparrow$ & 2 & $0 \downarrow$ \\
\hline
\end{tabular}

Megjegyzés: $A \uparrow$ és a $\downarrow$ nyilak jelzik, hogy a megfigyelt előfordulási gyakoriság nagyobb, illetve kisebb az elvárt előfordulási gyakoriságnál. Félkövérrel emeltük ki azokat a cellákat, ahol az eltérés mértéke magasabb volt, mint 2.

szinten maradt a regulációs szakaszban. A fapofa-szakaszban anyára negatív, viszont a regulációs szakaszban anyára vegyes (azaz anyára pozitív és anyára negatív társas viselkedést váltogató) mintázatú csecsemốk $81 \%$-ának csökkent a stressz-szintje a regulációs szakaszban. A fapofa-szakaszban anyára vegyes csecsemók esetében, akik a regulációs szakaszban anyára pozitívak lettek, nem mutatkozott stressz a regulációs szakaszban. A fapofa-szakaszban minimalizáló, majd a regulációs szakaszban anyára pozitív gyermekek 80\%-ánál szintén nem jelent meg stressz a regulációs szakaszban. Ugyanezt a társas mintázatot mutató két csecsemô esetén a regulációs szakasz elején tapasztalható stressz csökkent a regulációs szakasz végére. Érdekes, hogy a mindkét szakaszban anyára vegyes mintázatú csecsemók száma a regulációs szakasz stressz-szint-alakulásának három kategóriájában közel azonos volt. Megvizsgálva a kereszttáblán belül az elvárt és a megfigyelt gyakoriságok egymáshoz való viszonyát, feltûnô, hogy az ebbe a csoportba tartozó csecsemók vártnál kisebb arányánál $(28,6 \%)$ nem mutatkozott stressz. Ugyanakkor a várthoz képest nagyobb arányuknál $(35,7 \%)$ csökkent a stressz szintje, míg szintén 35,7\%-uknál a stressz szintje (nyügös vagy kiborult) állandó maradt, vagy növekedett a regulációs szakasz végére.

A változások alakulásában is minden esetben megvizsgáltuk a nemi és életkori különbségeket, azonban egyik esetben sem találtunk szignifikáns eltérést a nemek, illetve a korcsoportok között. 
Mintázati csoportok az érzelmi állapot, a társas viselkedés és a stressz-szint alakulása szerint: A klaszterelemzés eredményei

Kétlépcsôs klaszterelemzéssel vizsgáltuk, hogy az érzelmi állapot, a társas viselkedés és a stressz-szint változása, valamint az életkor és a nem alapján képződnek-e jellemzó csoportok, és ha igen, hány csoportot képez az elemzés. Az elemzésbe a fapofa- és a regulációs szakaszokban kódolt összes dimenziót bevontuk. A modell kohéziós értéke 0,4-es értékkel a fair kategóriába esik, tehát értelmezhető a próba eredménye. Két jól elkülönüloo csoportot kaptunk. A két csoport elkülönülésének fő diszkrimináló változójaként a csecsemók fapofa-szakaszban mutatott érzelmi állapota emelkedett ki. A két csoport leíró jellemzóit a 12. táblázat tartalmazza.

Az elsố klaszterbe $(\mathrm{N}=60)$ többségében a fapofa-szakaszban és a regulációs szakasz elején is nyugodt csecsemók kerültek. 86,7\%-uknál a regulációs szakaszban sem

12. táblázat. A csecsemôk két csoportja a fapofa-helyzet két szakaszában kódolt változók, valamint a nemek és az életkor alapján

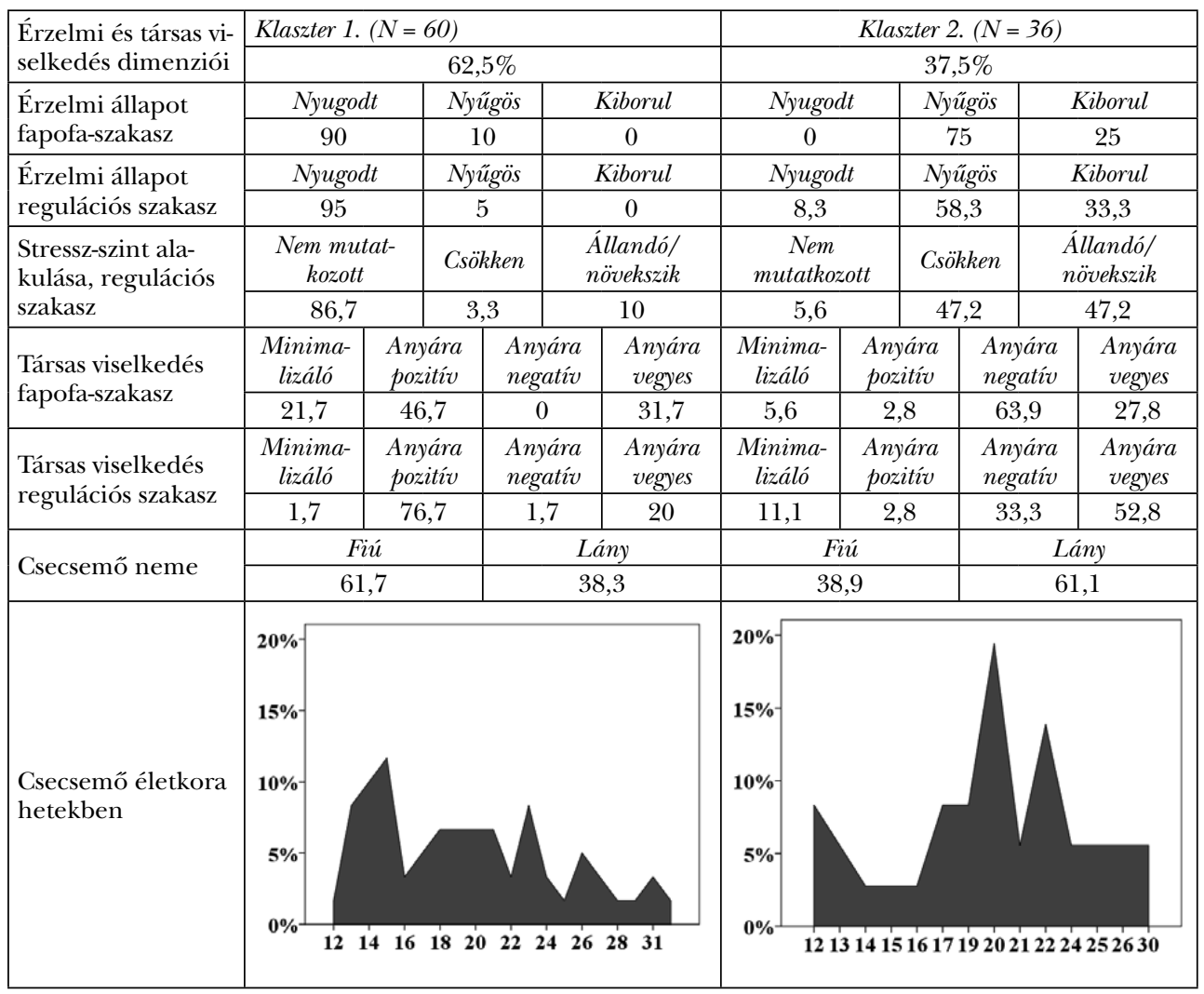

Megjegyzés: 1. A táblázat celláiban feltüntetett értékek az adott csoportba tartozó csecsemôk százalékos arányát jelentik. 2. A táblázatban a változók sorrendje a csoportosításban leginkább szerepet játszó dimenzióval kezdôdik és halad a legkevésbé befolyásoló változóig. A változók Predictor Importance mutatói sorrendben: 1,00; 0,97; 0,82; 0,70; 0,66; Csecsemố neme: 0,09; Csecsemô életkora: 0,01. 
jelentkezett stresszre utaló viselkedés. Ez alapján ezt a csoportot elneveztük „Nyugodt” csoportnak. A fapofa-szakaszban többségében anyára pozitív (46,7\%), anyára vegyes $(31,7 \%)$ vagy minimalizáló $(21,7 \%)$ társas mintázat jellemezte óket, míg a regulációs szakaszban a legtöbben $(76,7 \%)$ anyára pozitívak voltak, de elófordult az anyára vegyes társas viselkedés is $(20 \%)$. Az anyára negatív és a minimalizáló társas viselkedés csak elenyésző́n $(1,7 \%, 1,7 \%)$ jelent meg. Több fiú került ebbe a klaszterbe, mint lány, azonban a nemi különbség nem volt szignifikáns. A másik klaszterhez viszonyítva ebben a csoportban a fiatalabb, 12-16 hetes csecsemók voltak többségben, azonban itt sem mutatkozott szignifikáns korcsoporti különbség. A második klaszterbe $(\mathrm{N}=36)$ a fapofa-szakaszban nyúgös $(75 \%)$ vagy kiborult $(25 \%)$ csecsemók csoportosultak. Túlnyomó többségüknél a regulációs szakasz elején is fennmaradt a stressz (53,3\% nyúgös, 33,3\% kiborult), ezért ezt a csoportot elneveztük „Nyügös” csoportnak. A stressz a regulációs szakaszban egy részüknél csökkenó irányt mutatott (47,2\%), másik részüknél stagnált vagy emelkedett $(47,2 \%)$. Társas viselkedésükben az anyára vegyes $(52,8 \%)$, illetve az anyára negatív $(33,3 \%)$, kisebb részüknél $(11,1 \%)$ a minimalizáló mintázat dominált. A klaszterbe több lány került, mint fiú, de az eltérés statisztikailag itt sem volt szignifikáns. Az életkori eloszlásnál szintén nem kaptunk szignifikáns eltérést annak ellenére, hogy a grafikonon kiugrónak tûnik a 20 hetes csecsemôk nagyobb aránya a fiatalabbakéhoz képest.

\section{MEGBESZÉLÉS}

\section{Az Érzelmi és Társas Szabályozási Mintázatok Globális Kódrendszere}

Több kutatócsoport szerint (lásd például Barbosa és mtsai, 2018; Mesman és mtsai, 2009; Reck és mtsai, 2009) a fapofa-helyzetre kialakított, és az elemi viselkedések idôsoros elemzésén alapuló kódrendszerek többsége máig küzd azzal a problémával, hogy a csecsemókori stresszreguláció mintázatait olyan jól értelmezhetô, globális viselkedéses dimenziók segítségével írja le, amely dimenziók egymástól függetlenül, mégis egymással kölcsönhatásban is tudják vizsgálni a társas viselkedés és az érzelemkifejezés szerepét a regulációs mintázatok formálódásában. Az összetettebb, több elemi viselkedés komplex, egyidejú elôfordulását figyelembe vevô, globális kódoláson alapuló mintázatok keresése (lásd pl. Kogan és Carter, 1996) csak viszonylag késôbb lépett be a fapofa-paradigmával végzett kutatásokba. Alkalmazásuk több kutatócsoport szerint is számos elônnyel járhat a regulációs mintázatok felmérésében (az összefoglalót lásd Barbosa és mtsai, 2018, 2019; Mesman és mtsai, 2009). Kódrendszerünk kialakításakor a globális kódolást alkalmazó módszertani irányzat fejlôdéséhez kívántunk hozzájárulni. Arra voltunk kíváncsiak, hogy milyen érzelmi és társas mintázatok rajzolódnak ki 3-6 hónapos csecsemôknél a fapofa-helyzetben egy globális, az egyes viselkedéselemeket (érzelemkifejezés, vokalizáció, testhelyzet, illetve anya arcára/szemébe nézés) összetettségükben figyelembe vevô, mégis külön dimenziókat (érzelmi állapot, társas viselkedés és stressz-szint változása) kialakító kódrendszer segítségével. Jelen tanulmányban csak a csecsemó viselkedésmintáira koncentráltunk. Ugyanakkor szem elôtt tartottuk, hogy 
a regulációs mintázatok már 2-3 hónapos kortól tartalmazzák a diádikus interakciók reprezentációit (Beebe és mtsai, 2010; Stern, 1985), ezért feltételeztük - bár nem teszteltük -, hogy az egyéni mintázatok önmagukban is tükrözhetik a párra jellemzó szabályozási stratégiákat és azok eredményességét a csecsemô stressz-szintjének alakulásában a fapofa-helyzetben (Tronick, 2007). Jelen kódrendszerben, hasonlóan más tanulmányokhoz (lásd pl. Ekas és mtsai, 2013; Montirosso és mtsai, 2015), tehát kizárólag a csecsemố viselkedésére összpontosítottunk, és nem vizsgáltuk külön a reguláció gondozói aspektusát.

Kódrendszerünk sajátossága, hogy a csecsemó érzelmi állapotának, illetve az anyára irányuló társas viselkedésének jellemzését, valamint a stressz-szintjének alakulását három külön dimenzióra választottuk szét (2. és 3. táblázat). A dimenziókon belül globális viselkedés kategóriákat definiáltunk, a csecsemô jellemzô érzelmi állapotának, valamint az adott helyzetben domináns társas viselkedésének leírására. Ez utóbbi két dimenzióban lehetségesek átfedések, mivel mindkettôben figyelembe vettük a csecsemô érzelemkifejezésének minôségét. Ugyanakkor az érzelmi állapot dimenzióban definiált három kategória nem fedi le az anyára irányuló társas viselkedés során megfigyelt érzelmek definícióit. A definíciókban kiemelt szerepet kapnak az idôi kritériumok is. Eszerint, az érzelmi állapot dimenzióban a csecsemónek a teljes szakaszra jellemzô érzelmi állapotát kódoltuk, míg az anyára irányuló társas viselkedés dimenzióban az anyára irányuló társas viselkedés érzelmi töltetét. Bizonyos fokú átfedés a dimenziók között az érzelmi állapot és az érzelemkifejezés mentén nyilvánvaló lehet, hiszen például sokkal nagyobb a valószínúsége, hogy az érzelmi állapota alapján nyugodtnak ítélt csecsemó pozitív viselkedést mutat az anyára, mint hogy egy kiborult csecsemô mosolygással próbálná interakcióba hívni az édesanyját (Bigelow és mtsai, 2018). Klaszterelemzésünk (12. táblázat) azonban alátámasztja, hogy nincs teljes átfedés a két dimenzió között: a domináns érzelmi állapottal (nyugodt, illetve nyúgös) egy időben a csecsemôk anyára irányuló társas viselkedése attól eltérô affektív töltetú mintázatot mutathat. Például a nyugodt csecsemốk társas viselkedése lehet anyára pozitív vagy minimalizáló, illetve anyára vegyes is. A nyúgös érzelmi állapottal pedig mind a négy társas mintázat elófordulhat (12. táblázat). Ez az eredményünk egyrészt alátámasztja kódrendszerünkben az érzelmi állapot és a társas dimenziók függetlenségét, másrészt összhangban van Kogan és Carter (1996), valamint Tronick (2007) eredményeivel, miszerint a csecsemô társas viselkedésének affektív minôsége nincs teljes átfedésben a csecsemô fapofa-helyzetben mutatott érzelmi állapotával.

Összességében kódrendszerünknek három újdonsága van. (1) Az érzelmi állapot és a társas viselkedés dimenzióinak jellemzését a fapofa-helyzet mindkét szakaszában ugyanazokkal a kritériumokkal alkalmaztuk, és ezzel egységes alapokra helyeztük az egyes szakaszok elemzését. (2) A regulációs szakaszra vonatkozóan bevezettük a stressz-szint alakulását leíró dimenziót. (3) Az anyára irányuló társas viselkedés dimenzión belül bevezettük az anyára vegyes globális kategóriát, amelynél a csecsemók egyetlen szakaszon belül, másodpercenként is váltogathatják az anyára nézést pozitív, illetve negatív érzelemkifejezéssel, valamint a minimalizáló viselkedésmintázatot, amikor a csecsemốk aktívan kerülik az anyára tekintést, vagy ha ránéznek, azt semleges arckifejezéssel teszik. Egyik kategória sem jelenik meg önálló viselkedésmintázatként 
a szakirodalomban, a kódrendszerek többsége csupán a negatív, a pozitív, illetve a semleges/neutrális érzelemkifejezések elófordulását kalkulálja a társas viselkedéssel összefüggésben (Barbosa és mtsai, 2018; Coppola és mtsai, 2015; Montirosso és mtsai, 2015; Reck és mtsai, 2009). Azaz nem vonják be az érzelemkifejezés dinamikus folyamatának egészét - például az ellentétes előjelû érzelmek gyors váltogatását - a kommunikációs stratégia leírásába. Tronick (2005) Dyadic States of Consciousness modelljét továbbgondolva feltételeztük, hogy az általunk bevezetett két kategória olyan kommunikációs mintázatokat jelenthet, amelyek eltéró jelentést hordozhatnak a másik fél, azaz az anya számára a csak pozitív, a csak semleges, vagy csak negatív érzelemkifejezés üzenetértékeihez képest. Ezek jelentôségére a Mintázatok részben térünk vissza.

\section{A fapofa-hatás}

Az érzelmi állapot (nyugodt, nyúgös, kiborul) és a stressz-szint alakulása a regulációs szakaszban (stressz nem mutatkozik, stressz-szint csökken, stressz-szint állandó/növekszik) dimenziókon kapott eredményeink szerint a mintánkban egyértelmúen megjelent a klasszikus fapofa-hatás, azaz az anyai reciprok válaszkészség hirtelen megszakadására adott érzelmi reakció (Tronick és mtsai, 1978). A csecsemók többsége $(53,46 \%)$ a fapofa-szakasz alatt nyugodt marad, 33,66\%-a nyúgösködött, és csak 12,87\%-a borult ki. A regulációs szakaszban növekedett a nyugodt csecsemốk aránya $(62,5 \%)$, és csökkent a nyúgösködôké (5. és 7. táblázat). Ezek az arányok összhangban vannak a fapofa-hatást korábban leíró tanulmányok eredményeivel (lásd például Montirosso és mtsai, 2015), és leginkább a Barbosa és munkatársai (2018) által publikált arányokhoz hasonlítanak, akik szintén globális kódrendszerrel dolgoztak.

A szakirodalommal összhangban mintánkon is viszonylag kisebb arányban, 7 csecsemônél (9. táblázat) jelent meg az átcsapás jelensége, amikor a csecsemôk egy része a fapofa-szakaszban viszonylag nyugodt maradt, és csak a regulációs szakasz elején kezdett nyúgösködni. Ez az eredményünk alátámasztja, hogy a korábbi feltevésekkel szemben az átcsapás jelensége nem általánosan jellemzó ebben az életkorban (Mesman és mtsai, 2009). Mindkét eredményünk megerôsíti, hogy kódrendszerünkön belül az érzelmi állapot és a stressz-szint alakulása dimenziók önmagukban is - azaz a társas dimenzió bevonása nélkül - érvényesen jelzik a fapofa-hatást.

\section{Társas mintázatok a fapofa-helyzetben}

A mintázatok értelmezésében egyik fó kiindulópontunk volt Tronick (2005) Dyadic States of Consciousness modellje, amely feltételezi az aktív, értelmezó csecsemót, aki törekszik az anya jelentésadó és koherenciateremtô szerepének helyreállítására, amikor annak megszakadását tapasztalja. Hogy ezt milyen stratégiával és érzelemmel teszi, jelzi az anya-csecsemó pár egyénileg jellemzô regulációs mintázatait és annak interakciós elôtörténetét (Stern, 1985; Tronick, 2007).

A másik kiindulópontunk Mesman és munkatársai (2009) felismerése volt, miszerint a fapofa-helyzetben nem csupán a kommunikáció megszakadása lehet szokatlan 
és stresszkeltố a csecsemó számára, hanem az is, amikor az anya hirtelen ismét beszélni kezd a regulációs szakaszban. A csecsemố tehát egy második kihívással is találkozik, és az új helyzetet is értelmeznie kell ahhoz, hogy a megfelelő stratégiát alkalmazva részt vehessen a kölcsönösen harmonikus interakció helyreállításában. Ez alapján merült fel bennünk a kérdés, hogy a csecsemôk e kétfajta kihívást rejtô helyzetben azonos vagy eltérố társas mintázatot alkalmaznak-e az interakció és a saját stressz-szintjük szabályozására. A mintázatok változásával kapcsolatos kérdést a globális kódrendszerekkel dolgozó kutatásokban eddig még nem tették fel. Elemzésünkben ezért az anyára irányuló társas viselkedést megvizsgáltuk mindkét szakaszban, valamint ezek változását a fapofa-szakaszról a regulációs szakaszra.

A kódrendszerünkben definiált 4 fő társas mintázat a következó eloszlást mutatta. A csecsemók 28,71\%-a anyára pozitív, 25,73\%-a anyára negatív, 29,7\%-a-a anyára vegyes, és $14,85 \%$-a minimalizáló társas mintázatot mutatott a fapofa-szakaszban (5. táblázat). Ezek az arányok leginkább a Coppola és munkatársai (2015) kutatásában találtakhoz hasonlóak, akik kódrendszerükben az anyára irányuló társas viselkedést helyezték a középpontba. Ugyanakkor mégsem vethetők össze teljes mértékben, mivel ók csupán pozitív, negatív, illetve semleges kapcsolódási mintázatokat definiáltak, azaz nem képeztek olyan kategóriát, amelyet mi anyára vegyesnek, illetve minimalizálónak neveztünk.

A regulációs szakaszban ezek az arányok változtak. Jelentôsen nôtt az anyára pozitív $(48,95 \%)$, és csökkent az anyára negatív (13,54\%), illetve a minimalizáló viselkedés $(5,2 \%)$, míg az anyára vegyes mintázat elôfordulása enyhén növekedett $(32,29 \%)$ (7. táblázat). Kutatásunk újdonsága, hogy az előfordulási arányokon túl megvizsgáltuk a társas mintázatok változásának irányait is a fapofa-szakaszról a regulációs szakaszra. Eszerint a fapofa-szakasz domináns társas viselkedése két esetben jósolta be szignifikánsan a regulációs szakasz domináns társas viselkedését (10. táblázat és 1. ábra). A fapofa-szakaszban anyára pozitív csecsemók szignifikánsan nagyobb valószínúséggel alkalmazták ugyanazt a viselkedésmintázatot a regulációs szakaszban is. A fapofa-szakaszban minimalizálók pedig nagy valószínúséggel váltottak anyára pozitív viselkedésre. Három olyan mintázatot figyeltünk meg, amelyek változása bár nem bizonyult szignifikánsnak, de az előfordulási gyakoriságaik alapján (40-50\% között) mégis figyelemre méltónak gondoljuk: a fapofa-szakasz anyára negatív viselkedését viszonylag nagy valószínúséggel (48\%) váltotta fel anyára vegyes mintázat, és kisebb arányban (38\%) maradt meg az anyára negatív viselkedés. Az anyára vegyes esetén közel azonos arányban maradt ugyanaz a mintázat $(48 \%)$, mint amilyen arányban $(41 \%)$ azt anyára pozitív váltotta fel a regulációs szakaszban. Összességében, az anyára irányuló társas viselkedésmintázatok eloszlásában és a két szakasz közötti változásában, illetve változatlanságában nagy egyéni változatosság mutatkozott (1. ábra). Ez alátámasztja, hogy már 3 hónapos kortól is jelen lehetnek egyénre jellemzố regulációs mintázatok, valamint hogy a csecsemôk eltérôen reagálhatnak a kétfajta szituáció érzelmi és társas kihívásaira (Mesman és mtsai, 2009; Tronick, 2007). Az egyéni mintázatok leírását kiemelt jelentôségúnek gondoljuk a mintázatok adaptivitásának felmérése miatt is. 
Társas viselkedés és a stressz-szint alakulása: az egyéni mintázatok adaptivitása

A mintázatok adaptivitásának felméréséhez megvizsgáltuk, hogy a csecsemôk regulációs szakaszban mutatott stressz-szintjének alakulásában mutatkozik-e különbség aszerint, hogy hogyan alakult az anyára irányuló társas viselkedésük a fapofa-szakaszról a regulációs szakaszra. A társas viselkedés két szakasz közötti változása több esetben is bejósolta a stressz-szint alakulását a regulációs szakaszban (11. táblázat). Azokat a változásokat, amelyek egyértelmúen a stresszre utaló viselkedés hiányával (stressz nem mutatkozott), illetve a stressz-szint csökkenésével jártak együtt a regulációs szakaszban, adaptív mintázatként értelmeztük. Négy ilyen mintázatot találtunk: (1) amikor a csecsemô mindkét szakaszban anyára pozitív viselkedést mutatott, (2) amikor a fapofa-szakaszban anyára vegyes mintázata a regulációs szakaszban anyára pozitívra változott, (3) amikor a fapofa-szakaszban minimalizáló mintázatot anyára pozitív társas viselkedés váltotta fel, és (4) amikor a fapofa-szakaszban anyára negatív viselkedés anyára vegyes mintázatra változott. Azt a mintázatot, amelynél a stressz-szint a regulációs szakaszban magas volt és stagnált, vagy növekedett, rizikós mintázatként értelmeztük. Egyetlen ilyet találtunk, amikor a fapofa-szakaszban anyára negatív viselkedés a regulációs szakaszban is domináns mintázat maradt. Végül, többesélyes mintázatként értelmeztük a mindkét szakaszban anyára vegyes viselkedést, mivel ennél fordult elô, hogy a csecsemốk egy részénél a stressz hiányával, másik részénél annak stagnálásával, vagy növekedésével, illetve harmadik csoportjánál a stressz csökkenésével járt együtt a regulációs szakaszban (11. táblázat).

$\mathrm{Az}$ anyára vegyes társas viselkedést kiemelt jelentôségúnek tartjuk, mivel feltételezzük, hogy eltérô diádikus mintázat és kölcsönös regulációs történet állhat ugyanannak a viselkedésnek a hátterében attól függően, hogy milyen stressz-szinttel, illetve stressz-szint-változással jár együtt a csecsemônél a regulációs szakaszban. Eszerint lehet adaptív, ha a stressz-szint hiányával, illetve annak csökkenésével, és lehet kevésbé adaptív, amikor a stressz-szint növekedésével társul (vö. Tronick, 2007). Eredményünk alátámasztani látszik azt a feltevést, hogy ugyanazon társas viselkedésmintázat eltérô módon fonódhat össze a stresszreguláció eredményességével vagy eredménytelenségével (Gianino és Tronick, 1988; Tronick, 2005). A gondozói viselkedés elemzése és a diádikus mintázatok idôsoros kódolása tovább árnyalhatja ezeknek a mintázatoknak a felmérését, és következô elemzési céljaink közé tartozik. A mintázatok hosszú távú adaptivitására pedig egy utánkövetéses vizsgálat adhatna választ, melyhez jó kiindulópontot jelenthet a társas mintázatok és a stressz-szint összefüggésére kapott jelen eredményünk.

\section{Életkori és nemi különbségek a fapofa-hatásban és a társas mintázatokban}

Egyik szakaszban sem találtunk nemi és életkori különbségeket az érzelmi állapot (nyugodt, nyúgös, kiborul) és a stressz-szint változása dimenziókban (5., 6., 7., 8. táblázatok). A különbségek hiánya a normatív mintákra kapott eredményekkel (Barbosa és mtsai, 2018; Tronick és mtsai, 1978; Weinberg és Tronick, 1996) összhangban a fapofa-hatás életkortól és nemtôl való függetlensége mellett szól. Ugyanakkor az 5., a 7. és a 12. táblázatban szembeöltố a fiúk nagyobb aránya a nyugodt érzelmi csoportban a 
fapofa- és a regulációs szakaszban egyaránt. Bár ez az arány statisztikailag nem szignifikáns, mégis összhangban áll azokkal a kutatásokkal, amelyek a fiú-anya párok hatékonyabb összehangolódására és kölcsönös regulációjára hoztak bizonyítékot (pl. Carter és mtsai, 1990).

A társas stratégiák eloszlásában sem találtunk szignifikáns nemi és életkori különbségeket. A fiúknál és a lányoknál, valamint a 3 korcsoport esetén azonos arányban jelent meg az anyára pozitív, az anyára negatív, a minimalizáló és az anyára vegyes társas viselkedés a fapofa- és a regulációs szakaszokban egyaránt (5., 6., 7., 8. táblázatok). Az életkori stabilitás hipotézise alapján az életkori különbségek hiányát, míg a társas viselkedés fejlődésének 3, 4 és 5 hónapos korra jellemzó mérföldkövei alapján (lásd például Stern, 1985; Tronick, 2007) a különbségek megjelenését vártuk volna a kódrendszerünk társas viselkedés dimenziójában. A nemi és életkori különbségek hiánya a stabilitás hipotézist tûnik alátámasztani, és összhangban van a normatív mintákon kapott követéses vizsgálatok eredményeivel (Barbosa és mtsai, 2018; Cohn és Tronick, 1987). Eredményünk egyben azt a feltevést látszik erósíteni, hogy az interakciós készségek fejlôdése nem függ össze közvetlenül a szabályozási mintázatok kialakulásával (Remete, 2012). Bár vizsgálatunkban az életkori különbségek nem voltak szignifikánsak, mégis a leíró statisztika alapján szembeötlő, hogy az idôsebb csecsemôk a 3 hónaposokhoz képest nagyobb arányban alkalmazzák az anyára vegyes társas viselkedést a regulációs szakaszban (8. táblázat), ami felhívja a figyelmet arra, hogy egy nagyobb mintán vagy egy követéses vizsgálatban érdemes lenne tovább vizsgálni az életkori változások szerepét a regulációs mintázatok differenciálódásában, különösen azoknál a társas mintázatoknál, amelyek komplexebb üzeneteket küldenek a regulációs partner felé (Mesman és mtsai, 2009).

\section{Mintázati csoportok - a klaszterelemzés eredményei}

A fapofa-kutatások többféle klasztert azonosítottak a társas és érzelmi szabályozás leírásakor (összefoglalás lásd Barbosa és mtsai, 2018, 2019; Coppola és mtsai, 2015), azonban a kódrendszerek hátterében álló koncepciók eltérései miatt nagy fokú diverzitás tapasztalható a mintázatok definiálásában (Mesman és mtsai, 2009). Kutatásunkban ezért feltettük a kérdést, hogy az általunk kialakított globális kódrendszer dimenzióinak bevonásával kirajzolódnak-e jellemzô, a regulációs mintázatokat leíró fố klaszterek, és ha igen, azok létrejöttében mely dimenziók játszhatják a fő szerepet.

Vizsgálatunkban a csecsemók két csoportja különült el (12. táblázat). A nyugodt csoportba a csecsemók közel kétharmada, a nyúgös csoportba kicsivel több mint egyharmaduk került, ami összhangban van a fapofa-hatást kutató vizsgálatok jelentôs többségével (Mesman és mtsai, 2009). Emellett a fapofa-szakaszban megjelenô érzelmi minôség (nyugodt, nyúgös, kiborul) szerepe egyértelmúen kiemelkedett a klaszterek elkülönülésében. Ezt követte a regulációs szakasz érzelmi minósége, majd a stressz-szint alakulása a klaszterek formálódásában. A fapofa-, valamint a regulációs szakaszokban domináns társas viselkedéseknek ezzel szemben jóval kisebb volt a klaszterképzó ereje (12. táblázat), ami alátámasztja, hogy a társas stratégiák egyéni változatossága sokkal nagyobb, mint hogy fớ szerepet játszhatnának a csoportok létrejöttében. Ugyanakkor bejósló 
erejük támpontokat adhat ahhoz, hogy megvizsgálhassuk a két csoporton belüli eloszlásuk sajátosságait. Eszerint a nyugodt csoportra a fapofa-szakaszban túlnyomóan az anyára pozitív társas viselkedés és a vegyes viselkedésmintázat volt jellemzô. Ezzel szemben a nyúgös csoportban túlnyomóan az anyára negatív mintázat dominált, és szintén nagyarányú volt az anyára vegyes viselkedés, amely utóbbi a regulációs szakaszban jelentôsen növekedett. Az életkor és a nem szerepe statisztikailag elhanyagolható volt a klaszterek formálásában, mégis az ábrán látható, hogy a nyugodt csoportba több fiú és a fiatalabb csecsemôk kerültek, míg a nyúgös csoportba több lány és több idôsebb csecsemô.

Összegezve, eredményeink a korábbi klaszterelemzések mellett (lásd például Coppola és mtsai, 2015) új szempontokra hívják fel a figyelmet a globális dimenziók szerepével kapcsolatban. Úgy tûnik, a globális dimenziókkal képzett klaszterek differenciáltabb képet adhatnak az érzelmi és a társas dimenziók szerepérôl a regulációs mintázatok formálódásában. Egyben hozzájárulnak az egyéni mintázatok változatosságának leírásához és adaptivitásuk kutathatóságához is, ami napjainkban egyre inkább fókuszba kerül a fapofa-paradigmával végzett vizsgálatokban (Provenzi és mtsai, 2019).

\section{ÖSSZEFOGLALÁS}

Kutatásunkban 3-6 hónapos csecsemôk fapofa-helyzetben jelentkezô társas stratégiáit, érzelmi állapotát és stressz-szintjének változását vizsgáltuk egy általunk kialakított globális kódrendszer segítségével. Kódrendszerünk kialakításának egyik célja volt, hogy leírhassuk a társas és az érzelmi dimenziók egyénre jellemző sajátosságait a fapofa-helyzet két, egymástól eltérô kihívást jelentô szakaszában, és változásukat követni tudjuk a két szakasz között. Kódrendszerünk elônye, hogy e dimenziókat egymástól függetlenül is vizsgálhatjuk. Emellett együtt járásuk elemzése lehetôséget adhat az egyéni mintázatok azonosítására, valamint az egyes dimenziók szerepének elemzésére a mintázatok létrejöttében.

Eredményeinknek fejlődéslélektani és klinikai jelentôsége egyaránt van. A klaszterelemzés rávilágított, hogy a fapofa-hatásban az érzelmi dimenzió jelentôsége emelkedik ki a társas dimenzióval szemben az általunk vizsgált tipikus fejlốdésú mintán. Az érzelmi és a társas dimenziók szétválasztása igazolta, hogy a szabályozási mintázatokban változatosan jelenhetnek meg az anyára irányuló társas viselkedés egyénileg eltérô jellemzői. Mindez összhangban van Tronick (2005) modelljével, miszerint a csecsemốk már az elsốdleges interszubjektivitás kezdetétôl törekszenek a szokatlan és stresszkeltô kommunikációs helyzet értelmezésére, és egyéni mintázatokat alkalmazhatnak annak feloldására. Klinikai szempontból kiemelkedô jelentôségúnek tartjuk a társas viselkedésmintázatok és a stressz-szint alakulásának összefüggéseire vonatkozó eredményeinket, amelyek a mintázatok adaptív, illetve maladaptív jellegéról informálhatnak attól függôen, hogy az adott mintázat milyen stressz-szint-szabályozással társul.

Természetesen kutatásunknak több korlátja is van. A kódrendszerrel az adott dimenzión belül csupán egyetlen kóddal jellemezhetjük a csecsemó érzelmi állapotát, illetve domináns társas viselkedését, így a fapofa-helyzet egyes szakaszain belül nem tudjuk követni a változások idôi sorrendjét és azok dinamikáját. Jelen kutatásban nem 
vizsgáltuk a fapofa-helyzet elsô szakaszát, amely további predikciós lehetôségeket kínálhat az egyéni mintázatok, valamint a reciprok interakciók párra jellemzó folyamatának vizsgálatához. Az anyai viselkedés elemzése szintén nem tartozott jelenlegi céljaink közé, de a kutatás folytatásával további adatokkal bóvítheti majd a diádikus reguláció sajátosságainak és mintázatainak azonosítását, és ezen keresztül a csecsemó regulációs viselkedésének a megértését. Végül, jelen elemzésbe nem vontuk be azokat a változókat (a csecsemó fejlettségi állapota, a pre- és perinatális rizikótényezôk, illetve a szüloói faktorok), amelyek vizsgálata a következó lépésben tovább árnyalhatja kutatásunk fejlődéslélektani és klinikai céljait.

\section{KÖSZÖNETNYILVÁNÍTÁS}

A kutatás a Kisgyermekkori regulációs zavarok genetikai és epigenetikai háttere címú kutatási projekt részeként zajlott (kutatásvezetôk: Hámori Eszter, Barta Csaba), melyet a PPKE KAP16-71044-1.1-BTK és a KAP17-61001-1.1-BTK számú pályázatok támogattak. A kézirat elkészítésében Simon Réka Barbarát a KAP19-14020-1.7-BTK pályázata támogatta.

Köszönettel tartozunk a kutatásban részt vett családoknak, valamint a Pázmány Péter Katolikus Egyetem pszichológia szakos hallgatóinak, akik a vizsgálatok lebonyolításában és a kontroll kódolásban segédkeztek.

\section{IRODALOM}

Ainsworth, M. D. S. (1985). Patterns of Infant-Mother Attachments: Antecendents and Effects on Development. Bulletin of the New York Academy of Medicine, 61(9), 771-791.

Barbosa, M., Beeghly, M., Moreira, J., Tronick, E., \& Fuertes, M. (2018). Robust stability and physiological correlates of infants' patterns of regulatory behavior in the still-face paradigm at 3 and 9 months. Developmental Psychology, 54(11), 20-32.

Barbosa, M., Beeghly, M., Gonçalves, J. L., Moreira, J., Tronick, E., \& Fuertes, M. (2019). Predicting Patterns of Regulatory Behavior in the Still-Face Paradigm at 3 Months. Infancy, 24(4), 501-525.

Beebe, B., Jaffe, J., Markese, S., Buck, K., Chen, H., Cohen, P., Bahrick, L., Andrews H., \& Feldstein, S. (2010). The origins of 12-month attachment: A microanalysis of 4-month mother-infant interaction. Attachment \& Human Development, 12, 3-141.

Bigelow, A. E., \& Power, M. (2016). Effect of Maternal Responsiveness on Young Infants' Social Bidding-Like Behavior during the Still Face Task. Infant and Child Development, 25, 256-276.

Bigelow, A. E., Power, M., Bulmer, M., \& Gerrior, K. (2018). The Effect of Maternal Mirroring Behavior on Infants' Early Social Bidding During the Still-Face Task. Infancy, 23(3), 367-385.

Bowlby, J. (1969). Attachment and Loss: Volume 1: Attachment. The International Psycho-Analytical Library. 79, 1-401. London: The Hogarth Press and the Institute of Psycho-Analysis.

Carter, A. S., Mayes, L. C., \& Pajer, K. (1990). The role of dyadic affect in play and infant sex in predicting response to the still-face situation. Child Development, 61, 764-773. 
Cohn, J. F., Campbell, S. B., \& Ross, S. (1992). Infant response in the still-face paradigm at 6 months predicts avoidant and secure attachment at 12 months. Development and Psychopathology, 3, 367-376.

Cohn, J. F., \& Tronick, E. Z. (1987). Mother-infant face-to-face interaction: The sequence of dyadic states at 3, 6, and 9 months. Developmental Psychology, 23, 68-77.

Coppola, G., Aureli, T., Grazia, A., \& Ponzetti, S. (2015). Reunion Patterns in the Still-Face Paradigm as Predicted by Maternal Sensitivity and Dyadic Coordination. Infancy, 21(4), 453-477.

Ekas, N. V., Haltigan, J. D., \& Messinger, D. S. (2013). The dynamic still-face effect: do infants decrease bidding over time when parents are not responsive? Developmental Psychology, 49(6), $1027-1035$.

Gianino, A., \& Tronick, E. Z. (1988). The mutual regulation model: The infant's self and interactive regulation and coping and defensive capacities. In Field, T., McCabe, P., \& Schneiderman, N. (Eds), Stress and Coping (pp. 47-68). Hillsdale, NJ: Erlbaum.

Giusti, L., Provenzi, L., \& Montirosso, R. (2018). The Face-to-Face Still-Face (FFSF) Paradigm in Clinical Settings: Socio-Emotional Regulation Assessment and Parental Support With Infants With Neurodevelopmental Disabilities. Frontiers in Psychology, 9, 789. https://doi. org/10.3389/fpsyg.2018.00789

Kogan, N., \& Carter, A. S. (1996). Mother-infant reengagement following the still-face: The role of maternal emotional availability in infant affect regulation. Infant Behavior \& Development, 19(3), 359-370.

Li, W., Woudstra, M. L. J., Branger, M. C., Wang, L., Alink, L. R., Mesman, J., \& Emmen, R. A. (2019). The effect of the still-face paradigm on infant behavior: A cross-cultural comparison between mothers and fathers. Infancy, 24(6), 893-910.

MacLean, P. C., Rynes, K. N., Aragón, C., Caprihan, A., Phillips, J. P., \& Lowe, J. R. (2014). Mother-infant mutual eye gaze supports emotion regulation in infancy during the Still-Face paradigm. Infant Behavior \& Development, 37(4), 512-522.

Melinder, A., Forbes, D., Tronick, E., Fikke, L., \& Gredebäck, G. (2010). The development of the still-face effect: Mothers do matter. Infant Behavior and Development, 33(4), 472-481.

Mesman, J., Van IJzendoorn, M. H., Bakermans-Kronenburg, M. (2009). The many faces of the Still-Face Paradigm: A Review and Meta-analysis. Developmental Review, 29, 120-162.

Montirosso, R., Casini, E., Provenzi, L., Putnam, S. P., Morandi, F., Fedeli, C., \& Borgatti, R. (2015). A categorical approach to infants' individual differences during the Still-Face paradigm. Infant Behavior and Development, 38, 67-76.

Murray, L., \& Trevarthen, C. (1985). Emotional regulation of interactions between two-month-olds and their mothers. In Field, T. M., \& Fox, N. A. (Eds), Social perception in infants (pp. 177-197). New Jersey: Ablex.

Provenzi, L., Giusti, L., Fumagalli, M., Frigerio, S., Morandi, F., Borgatti, R., et al (2019). The dual nature of hypothalamic-pituitary-adrenal axis regulation in dyads of very preterm infants and their mothers. Psychoneuroendocrinology, 100, 172-179.

Provenzi, L., Giusti, L., \& Montirosso, R. (2016). Do infants exhibit significant cortisol reactivity to the Face-to-Face Still-Face paradigm? A narrative review and meta-analysis. Developmental Review, 42, 34-55.

Provenzi, L., Olson, K. L., Montirosso, R., \& Tronick, E. (2016). Infants, mothers, and dyadic contributions to stability and prediction of social stress response at 6 months. Developmental Psychology, 52(1), 1.

Reck, C., Noe, D., Cenciotti, F., Tronick, E., \& Weinberg, K. M. (2009). Infant and Caregiver Engagement Phases, German revised ed (ICEP-R). Unpublished Manuscript. Heidelberg: University of Heidelberg. 
Reck, C., Tietz, A., Müller, M., Seibold, K., \& Tronick, E. (2018). The impact of maternal anxiety disorder on mother-infant interaction in the postpartum period. PloS One, 13(5), e0194763.

Remete, E. (2012). Fejlôdési változások a fapofa (Still-Face) helyzetben megfigyelt anya-csecsemố interakciókban. Pszichológia, 32(3), 211-228.

Stern, D. (1985). The interpersonal world of the infant. New York: Basic Books.

Tronick, E. Z. (2005). Why is connection with others so critical? The formation of dyadic states of consciousness and the expansion of individuals' states of consciousness: Coherence governed selection and the co-creation of meaning out of messy meaning making. In Nadel, J., Muir, D. (eds), Emotional development: Recent research advances (pp. 293-315). Oxford, England: Oxford University Press.

Tronick, E. (2007). The neurobehavioral and social-emotional development of infants and children. WW Norton \& Company.

Tronick, E. Z., Als, H., Adamson, L., Wise, S., \& Brazelton, T. B. (1978). The infant's response to entrapment between contradictory messages in face-to-face interaction. Journal of the American Academy of Child Psychiatry, 17, 1-13.

Tronick, E., Als, H., \& Brazelton, T. B. (1980). Monadic phases: A structural descriptive analysis of infant-mother face to face interaction. Merrill-Palmer Quarterly of Behavior and Development, 26(1), 3-24.

Tronick, E. Z., \& Cohn, J. F. (1989). Infant-mother face to face interaction: age and gender differences in coordination and the occurrence of miscoordinations. Child Development, 60, 85-92. 10.2307/1131074

Weinberg, M. K., \& Tronick, E. Z. (1996). Infant affective reactions to the resumption of maternal interaction after the still-face. Child Development, 67, 905-914. 


\title{
EMOTIONAL AND SOCIAL BEHAVIORAL PATTERNS IN THE STILL FACE PARADIGM IN 3-6 MONTH-OLD INFANTS
}

\author{
HÁMORI, ESZTER - SIMON, RÉKA BARBARA- MÁRKUS, LILLA VIKTÓRIA - \\ FARKAS, FLÓRA
}

Background and aims: The Face-to-Face-Still-Face Paradigm (FFSF, Tronick et al, 1978) artificially generates an unusual perturbation in the infant-mother interaction and as such has become a widely used procedure in the investigation of individual and dyadic social and stress regulation in infancy. The various coding systems, however, have brought about controversial results in the identifications of regulatory patterns. One of our aims was to develop a global coding system, by means of which the role of the social and emotional regulatory behaviors in the formations of organized regulatory patterns could be evaluated separately. Our second aim was to search for social behavior patterns exhibitive of the Still Face and Regulatory episodes as well as to examine their changes from one episode to to other.

Method: The FFSF paradigm was administered to 101 typically developing 3-6 months-old infant-mother dyads. The emotional state, the social behavior and the changes in the stress level of the infant were evaluated in two episodes of the FFSFP by the Global Coding System of Emotional and Social Regulatory Patterns that has been developed for the purpose of this study.

Results: The classical Still-Face effect has been clearly demonstrated by the results of the emotional state dimension. Beyond this, we identified four social regulatory patterns: positive-to-mother, negative-to-mother, ambivalent-to-mother and minimization. The dominant social patterns in the Still-Face episode predicted variously those in the Reunion episode. Different patterns of the interrelations of the changes in social strategies and the stress level in the Reunion episode could be identified as adaptive, risk and multi chance patterns. Two groups of infants have been separated by the cluster analysis, the calm and the fussy groups. Emotional dimension, as contrast to social dimension, has emerged as significant clustering predictor.

Conclusion: Our results support the hypotheses that individual stress regulatory patterns can be present from as early as three months of infant age. Our coding system draws attention to the importance of global behavioral coding dimensions that can inform us about the interconnection between the complex emotional and social behavior patterns and the stress regulation and thus can contribute to the exploration of their adaptive versus maladaptive nature.

Keywords: Still-Face Paradigm, 3-6 months-old infants, Global Coding System of Emotional and Social Regulatory Patterns, adaptive and risk regulatory patterns

A cikk a Creative Commons Attribution 4.0 International License (https://creativecommons. org/licenses/by/4.0) feltételei szerint publikált Open Access közlemény, melynek szellemében a cikk bármilyen médiumban szabadon felhasználható, megosztható és újraközölhetô, feltéve, hogy az eredeti szerzố és a közlés helye, illetve a CC License linkje és az esetlegesen végrehajtott módosítások feltüntetésre kerülnek. (SID_1) 